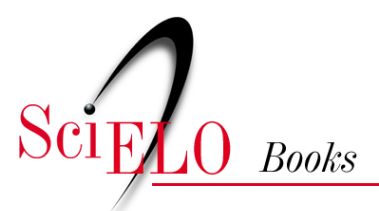

\title{
Michel de Certeau e as pesquisas nos/dos/com os cotidianos em educação
}

\author{
Carlos Eduardo Ferraço \\ Maria da Conceição Silva Soares \\ Nilda Alves
}

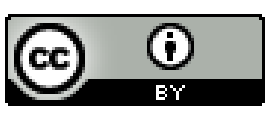

All the contents of this work, except where otherwise noted, is licensed under a Creative Commons Attribution 4.0 International license.

Todo o conteúdo deste trabalho, exceto quando houver ressalva, é publicado sob a licença Creative Commons Atribição 4.0.

Todo el contenido de esta obra, excepto donde se indique lo contrario, está bajo licencia de la licencia $\underline{\text { Creative Commons }}$ Reconocimento 4.0. 


\section{Michel de Certeau e as pesquisas nos/dos/com os cotidianos em Educação}




\section{UNIVERSIDADE DO ESTADO DO RIO DE JANEIRO}

\section{Reitor}

Ruy Garcia Marques

Vice-reitora

Maria Georgina Muniz Washington

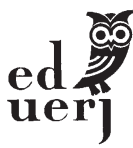

EDITORA DA UNIVERSIDADE DO ESTADO DO RIO DE JANEIRO

\section{Conselho Editorial}

Glaucio José Marafon (presidente)

Henriqueta do Coutto Prado Valladares

Hilda Maria Montes Ribeiro de Souza

Italo Moriconi Junior

José Ricardo Ferreira Cunha

Katia Regina Cervantes Dias

Lucia Maria Bastos Pereira das Neves

Luciano Rodrigues Ornelas de Lima

Maria Cristina Cardoso Ribas

Tania Maria Tavares Bessone da Cruz Ferreira

Anibal Francisco Alves Bragança (EdUFF) 


\author{
Carlos Eduardo Ferraço
}

Maria da Conceição Silva Soares

Nilda Alves

\title{
Michel de Certeau e as pesquisas nos/dos/com os cotidianos em Educação
}

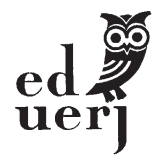

Rio de Janeiro

2018 
Copyright (c) 2018, EdUERJ.

Todos os direitos desta edição reservados à Editora da Universidade do Estado do Rio de Janeiro. É proibida a duplicação ou reprodução deste volume, ou de parte do mesmo, em quaisquer meios, sem autorização expressa da editora.

\section{EdUERJ}

Editora da Universidade do Estado do Rio de Janeiro

Rua São Francisco Xavier, 524 - Maracanã

CEP 20550-013 - Rio de Janeiro - RJ - Brasil

Tel./Fax.: 55 (21) 2334-0720 / 2334-0721

www.eduerj.uerj.br

eduerj@uerj.br

Editor Executivo

Glaucio Marafon

Coordenadora Administrativa

Elisete Cantuária

Coordenadora Editorial

Silvia Nóbrega

Assistente Editorial

Thiago Braz

Coordenador de Produção

Mauro Siqueira

Supervisor de Revisão

Elmar Aquino

Revisão

Iris Figueiredo

João Martorelli

Capa, Projeto e Diagramação

TipoIsso Design

L368 Ferraço, Carlos Eduardo.

Michel de Certeau e as pesquisas nos/dos/com os cotidianos em educação / Carlos Eduardo Ferraço, Maria da Conceição Silva Soares, Nilda Alves. - Rio de Janeiro : EdUERJ, 2018.

$112 \mathrm{p}$.

ISBN 978-85-7511-474-2

1. Certeau, Michel de, 1925-1986. 2. Educação. I. Soares, Maria da Conceição Silva. II Alves, Nilda. III. Título.

CDU 37 
Nossas ciências surgiram com o gesto histórico "moderno" que despolitizou a pesquisa ao instaurar campos "desinteressados" e "neutros", apoiados por instituições científicas. Esse gesto continua organizando, frequentemente, a ideologia exibida por alguns círculos científicos. Mas o desenvolvimento do que se tornou possivel por esse gesto acabou por inverter seu alcance. [...] Atualmente, convém, portanto, "politizar de novo" as ciências. Michel de Certeau (apud Ferraço, 2011, p. 63) 


\section{Sumário}

INTRODUÇÃO 9

Viajantes em busca da alteridade e da compreensão das dinâmicas de criação da vida e do conhecimento

CAPÍTULO 1

História-ficção-narrativa de vida em Certeau

CAPÍTULO 2

A crítica à epistemologia da ciência e a aposta na atitude ético-estética em pesquisa

CAPÍTULO 3

A potência das práticas e as artes de fazer com

CAPÍTULO 4

Cotidiano, cultura, alteridade e a criação permanente de diferença

CAPÍTULO 5

A pesquisa nos/dos/com os cotidianos em educação

REFERÊNCIAS 


\section{INTRODUÇÃO}

\section{Viajantes em busca da alteridade e da compreensão das dinâmicas de criação da vida e do conhecimento}

Neste livro nos propomos a apresentar e conversar com algumas ideias do pensador francês Michel de Certeau (1925-86), nosso velho conhecido. Veremos como as "usamos", da maneira que ele propôs, para, em diálogo com outros pensadores e com os praticantespensantes (Oliveira, 2012) da cultura, pensar o que se cria no dia a dia da vida nas/com as escolas e nas/com as múltiplas redes educativas. Redes nas quais vivemos, formamos e nos formamos, pesquisamos e aprendemosensinamos, na tendência em pesquisa que há mais de vinte anos vem se constituindo e consolidando como Pesquisas nos/ dos/com os cotidianos em Educação.

Quanto mais lemos Certeau, mais nos damos conta da atualidade de suas ideias. Também notamos a potência de sua proposta/aposta teórico-metodológico-epistemológico-política para pensar a contemporaneidade e os modos possíveis para nos movimentarmos no mundo, diferindo e tecendo outras/ novas possibilidades para a produção de conhecimentos e para uma vida afirmativa no encontro com o Outro, com a alteridade, informados por interesses e desejos de seus praticantespensantes para muito além, e apesar do que é imposto pelos mercados e pelas políticas de Estado, quiçá pelas políticas que nos são enfiadas goela abaixo pelos administradores do mundo neoliberal e globalizado.

Nós, os cotidianistas - como são conhecidos os pesquisadores que se reconhecem nessa tendência em pesquisa - , te- 
mos, durante todo esse tempo, produzido diálogos com/entre Certeau e com/entre diferentes autores, conforme as demandas dos cotidianos aos quais nos dedicamos. São nomes como Bruno Latour, Homi Bhabha, Boaventura de Sousa Santos, Michel Foucault, Gilles Deleueze, Félix Guattari, Edgar Morin e Judith Buttler, entre outros. Nossos interesses em pesquisa também são variados, abarcando diferentes temáticas que atravessam a Educação, como currículo, avaliação, formação de professores, práticas docentesdiscentes, usos das mídias e tecnologias da comunicação e informação, aprendizagens com as artes e com os espaçostempos das cidades, a diáspora dos afrodescendentes, a intolerância religiosa, o racismo e as disputas em torno das questões de gênero e sexualidade, entre outros.

Em comum, temos a aposta nos cotidianos como espaçostempos de criação de conhecimentos e de produção da vida social, além de uma atitude em pesquisa implicada com os praticantespensantes das escolas e das redes educativas e com os saberesfazeres que eles tecem nas redes, que por sua vez compõem uma trama de conhecimentos e artes de fazer nos diferentes contextos em que vivem, criando sempre diferenças com o desvio produzido pelas práticas. Essa atitude - de insubmissão e invenção de outras possibilidades diante do que nos oprime - que restringe e/ou constrange encontramos no modo como percebemos e interpretamos a trajetória de vida do próprio Certeau.

Michel de Certeau - historiador-vagabundo e jesuíta-errante, conforme definição astuciosa de Diana Gonçalves Vidal (2005) - foi um intelectual atento às práticas, às crenças e às invenções cotidianas que forjaram as redes de saberesfazeres, as relações de poder, as transformações culturais, as crises institucionais e as tensões sociais que agitaram e conformaram os espaçostempos em que trabalhou, estudou, militou, escreveu, visitou 
e viveu com outros. Sacerdote, professor e pesquisador, Certeau transitou por múltiplos caminhos já percorridos pelo pensamento e pelos pensadores, abriu trilhas para explorar novas sensibilidades e atravessou fronteiras entre campos do conhecimento, lugares e épocas; produzindo, permanentemente, diferença com sua trajetória acadêmica, religiosa, política e existencial.

Certeau aonde sua curiosidade, sua fé, seu projeto de trabalho e sua abertura para a alteridade o levaram. Caminhou com um olho nos indícios do que poderia ter sido o passado e outro no que poderia vir a ser o presente; um pé na igreja católica, com seus rituais e dogmas, e outro na ciência, com suas rotinas produtivas e verdades produzidas; um ouvido sintonizado com o burburinho e a polissemia da fala das ruas e outro atento aos discursos que insinuavam falar em nome da verdade e do real; uma mão ocupada em exercitar gestos e rituais milenares e outra dedicada à escrita que fabulava outros mundos possíveis. Para Giard (2011), a unidade de todas as atividades do corpo e da mente em conjunção conferia um estilo único e inimitável ao trabalho da inteligência de Certeau.

Michel de Certeau, conforme Giard (2011, p. 7), tinha uma maneira inimitável para atravessar as fronteiras entre os campos do saber: "Não se incomodava em esperar um salvo-conduto no posto fronteiriço, tampouco em solicitar a autorização dos guardiões de determinado feudo". Em seu processo de formação, mas também em seu trabalho, integrou diferentes disciplinas das ciências humanas e sociais: História, Filosofia, Teologia, Antropologia, Sociologia, Psicanálise, Semiótica, entre outras. Ele não hesitava em avançar por diferentes campos, inventando o melhor percurso de investigação para abordar seu objeto de reflexão. Ainda para o autor, tal atitude gerava uma força, um elã contagioso. Para Cravetto (2003), era uma espécie de obsessão pela relação imprevisível entre ruptura e luto que 
pontuava, no trabalho de Certeau, a representação da própria vida. Trata-se, segundo ela, de uma lesão inicial, geradora da atividade criadora, e também a superação da mesma lesão.

Para Certeau, conforme o concebemos, o Outro com o qual permanentemente se defrontava era, em potência, o mistério, a estranheza e a permanente surpresa, portanto, o imprevisível, no encontro com o qual poderia se estabelecer a crise do crível, ou seja, a quebra dos padrões habituais de referências, valores, pensamentos e ações. Um vazio em relação ao que era tido como certo, ao que era admitido e desejado. Com o sentimento de perda viria então o luto, e depois dele, a não identificação e a abertura para a alteridade radical e para as mudanças que esse deslocamento possibilita. Nas palavras do próprio Certeau (1970, p. 7),

Habitualmente, o estranho circula discretamente sob nossas ruas. Mas, é suficiente uma crise para que, de todos os lados, como que trazido por uma enchente, ele suba do sub-solo [sic], levantando as coberturas dos esgotos, invadindo os andares baixos e, em seguida, toda a cidade. Que o noturno apareça, brutalmente, à luz do dia, é coisa que, a cada vez, surpreende. Esta força a descoberto se insinua nas tensões da sociedade que ela ameaça. Frequentemente, ela as agrava; utiliza ainda os meios e os circuitos existentes, mas ao serviço de uma "inquietude" que vem de mais longe e que não se espera; ela quebra as fechaduras; ela faz transbordar as canalizações sociais; ela abre caminhos que deixarão, após sua passagem, quando o fluxo se retira, uma outra paisagem e uma ordem diferente.

Com uma atitude epistemológica em que articulava diferentes conhecimentos e modos de conhecer forjados em diferentes campos e contextos, Michel de Certeau elaborou, ao longo de sua trajetória, novos objetos de estudo e novos procedimentos 
metodológicos. Apesar da diversidade dos temas e dos espaçostempos estudados, sua obra desenvolveu-se em torno de domínios identificáveis: a escrita da história ou a operação historiográfica, a história das crenças, a mística e a espiritualidade, a psicanálise, a cultura em sua pluralidade/multiplicidade, as mídias e as tecnologias da informação e as práticas culturais cotidianas.

Tendo iniciado sua investigação histórica com trabalhos sobre a mística cristã medieval, escreveu ensaios sobre os acontecimentos de Maio de 1968 e sobre o declínio do cristianismo na contemporaneidade; investigou a epistemologia da história e, por tabela, das ciências sociais; analisou as transformações culturais produzidas pelas mídias, pelas migrações, pelas minorias nascentes e pela ascensão das massas às universidades; e desenvolveu metodologias e conceitos que potencializam a compreensão e valorização das artes de dizer e de fazer cotidianas.

Apesar da aparente dispersão entre interesses, métodos e domínios de campos do saber que poderiam caracterizar a sua obra à primeira vista, Maigret (2000) sugere que um projeto de análise da modernidade emanava de seus escritos. Segundo ele, esse projeto começou com o estudo do misticismo como uma manifestação de secularização e com o estudo da secularização como invenção de um espaço autônomo de práticas culturais. Nessa direção, uma nova teoria de crenças e práticas, e as ligações entre elas, completaria um projeto que buscava identificar as mudanças trazidas pela modernidade.

Os deslocamentos que experimentou com as tantas viagens (físicas ou intelectuais) que fez ao encontro do Outro, da alteridade, e as desnaturalizações em relação ao que era tido como habitual e já sabido com eles engendradas lhe possibilitaram investir em uma combinatória de procedimentos investigativos e analíticos. Isto resultou em uma perspectiva de abordagem da constituição e transformação do social inédita e alternativa em 
relação às abordagens tradicionais à época, entre elas o marxismo e o estruturalismo.

De acordo com Maigret (2000), ao apontar a potência transformadora e a insubmissão produzidas pelas práticas cotidianas realizadas por homens e mulheres comuns, Certeau refutou as ideias de alienação e de determinismo, instituindo, na nossa compreensão, a possibilidade de uma análise crítica e otimista (mas não ingênua) da ação social no contexto das relações desiguais de poder, a qual, para alguns estudiosos de seu trabalho, como Maigret (2000), Josgrilberg (2005) e Vidal (2005), inscreve-se no campo dos Estudos Culturais.

No entrecruzamento de métodos que praticou sem prestar vassalagem a nenhum deles (Giard, 1994, p. 10), o aporte da Psicanálise pode ter sido importante para a escuta dos sinais que vêm de um Outro que é inapreensível em sua estranheza, falta ou ausência. Conforme Assunção (2005, p. 37):

A Psicanálise, assim como a História, emprega mecanismos semelhantes na construção desse saber: ambas, buscam por meio dos vestígios, dos restos, dos indícios, dos traços, dos sinais... /fontes, um modo de preenchimento de um vazio sempre a ser preenchido... a presença destes não implica presença absoluta; ela é sempre uma presença da falta, de uma ausência... é preciso escutar cada uma delas e o sujeito do qual elas falam.

A escuta atenta e a abertura para o Outro, para a diferença, para a diversidade, para a alteridade, permeia toda a obra de Michel de Certeau, caracterizando a atitude ético-política que o moveu. Mas, quem é o outro? Ou melhor, quem são os outros para Certeau? Arriscamo-nos a afirmar que, para ele, o Outro é, primeiramente, Deus. "O Deus da minha fé não cessa de frustrar e guiar o desejo que busca compreendê-lo. Ele o frustra porque 
nada do que eu sei é Ele. Ele o guia porque eu não o esperava lá aonde ele vem... ele só é o Mesmo aparecendo como Outro" (Certeau, 2006, p. 5).

O reconhecimento do declínio da influência da Igreja diante das mudanças sociais de sua época, provocadas em grande parte pelas migrações e pelas tecnologias da comunicação, lhe colocou o desafio e a tarefa cristã de restabelecer a comunicação de forma aberta com os Outros. Nessa perspectiva, abrir-se ao estrangeiro seria atualizar a linguagem e os significados diante da presença do Outro (Josgrilberg, 2005).

O Outro, no entanto, assume diferentes configurações nos escritos de Certeau. O Outro é o que tem outros valores, crenças, hábitos, saberes. O Outro é aquele ou aquilo que emerge com as crises do crível e engendra credibilidades nascentes. O Outro é aquele ou aquilo que não se possui nem se controla. O Outro é o que escapa. É o imprevisível, o inesperado, o excluído, o imigrante, o marginalizado, o estrangeiro. O Outro é mistério e é surpresa. É a alteridade radical, a diferença para a qual nós precisamos nos abrir para criar.

Considerando a complexidade e a operacionalidade da abordagem, Cravetto (2003) assinalou que em períodos de crise e desordem social e política, quando temos dificuldades para esclarecer as mudanças que estão ocorrendo, torna-se tarefa urgente e necessária voltarmos ao projeto de Certeau, o qual, segundo ela, pode ser caracterizado pelo trabalho de reconhecimento constante do aqui e agora, o que pressupõe uma emancipação do pensamento, um processo que comporte uma interrogação inventiva de saberes e uma elaboração rigorosa de conhecimentos que não seja subserviente aos modelos ideológicos dominantes.

Michel de Certeau era, para Luce Giard (1994, p. 9) um desses espíritos "anticonformistas e perspicazes", "cuja irradia- 
ção intelectual segue caminhos estranhos à lógica das instituições, quer estas se achem ligadas à Universidade, à Igreja ou ao Estado". Estava sempre em movimento e nunca se identificava a um lugar. Ele era ainda adolescente quando a Segunda Grande Guerra eclodiu na Europa e atuou, por um breve período, em um grupo de resistência ao nazismo.

Estava em Paris em maio de 1968, quando se propôs a pensar as manifestações e as mudanças sociais que estavam em curso em meio ao clamor dos acontecimentos. Em suas andanças pelo mundo, conheceu a desigualdade social, o autoritarismo, a exploração econômica, a miscigenação, o preconceito, a exclusão e a pobreza; mas também foi capaz de enxergar, acima de tudo, o poder de resistência, de negociação, de hibridização e de invenção engendrados com as práticas culturais cotidianas.

Esteve no Brasil pela primeira vez em 1966, período da ditadura militar, sensibilizado com a situação política do país. O conhecimento sobre o Brasil, contudo, de acordo com Vidal (2005), antecedia às viagens e vinha de leituras, entre elas, trabalhos de Paulo Freire. Apoiado no educador brasileiro, Michel de Certeau, em um artigo que escreveu para a revista Pédagogie, concebeu a relação pedagógica como um diálogo entre gerações e a aula como um lugar onde se deve exercitar a liberdade.

Em A cultura no plural, tocado por maio de 1968, Certeau refletiu sobre as escolas, as universidades e as mudanças culturais, mas foi a obra $A$ invenção do cotidiano que obteve melhor recepção e que foi mais apropriada no Brasil, produzindo ressonâncias nas Ciências Humanas e Sociais.

Nessa perspectiva, defendemos que a contribuição de Certeau ao campo da Educação é inestimável e, além de sua atitude política e em pesquisa, se substancializa na crítica à epistemologia das Ciências Socais e Humanas e, principalmente, 
em sua empreitada teórica para construir uma epistemologia das práticas cotidianas, as quais estão, segundo ele, no cerne da constituição e transformação do social, do cultural, do político, do científico e do educativo, mobilizando procedimentos metodológicos e criando conceitos para apreendê-las e analisá-las. 


\section{CAPÍTULO 1}

\section{História-ficção-narrativa de vida em Certeau}

Alguém pergunta: mas o que 'querem' dizer? Então se responde: vou contá-los de novo. Se alguém lhe perguntasse qual era o sentido de uma sonata, Beethoven, segundo se conta, a tocava de novo (Certeau, 1994, p. 155).

\section{Ponto de partida}

A escrita de uma biografia sempre implica escolhas do que consideramos relevante ou não de ser narrado. Ao selecionarmos as informações que serão usadas em nossas narrativas, acabamos por potencializar sentidos que, como nos ensina o próprio Certeau (1994, p. 162), “[...] devem brilhar como uma metonímia em relação a esse todo”. Assim, as escolhas que fazemos são sempre parciais e arbitrárias, uma vez que priorizam determinadas informações, a partir das quais evidenciaremos um mito, enquanto outras ficam no esquecimento.

Mas, que significa entender uma biografia como mito? Quadros (2002) responde a essa pergunta ponderando que, assim como o mito, uma biografia é sempre reinventada com características fictícias ao tentar explicar sua origem. Recorrendo a Certeau (1994, p. 182), teríamos que um mito “[...] é um discurso relativo ao lugar/não lugar (ou origem) da existência concreta, um relato bricolado com elementos tirados de lugares 
comuns, uma história alusiva e fragmentária cujos buracos se encaixam nas práticas sociais que simboliza”.

Desse modo, em nossas tentativas de narrar fios da história de vida de Certeau, estaremos nos aproximando da criação em redes de um espaço de ficção, que se afasta de toda e qualquer pretensão de retratar a realidade e a veracidade dos acontecimentos vividos, "produzindo efeitos e não objetos. É narração, não descrição. É uma arte do dizer” (Certeau, 1994, p. 154), que exerce uma arte do pensar.

Para tanto, nos valemos de diferentes textos-memórias-narrativas de autores e autoras que se dedicaram a fazer biografias ou, mais modestamente, apresentar alguns fatos da vida de Michel de Certeau. Durante as leituras desses textos-memórias, sempre nos acompanhou a sensação de que se tratava de exercícios que pudessem estabelecer relações entre aspectos biográficos e o pensamento do autor. Em nosso caso, deixamos esses exercícios a critério dos leitores e leitoras que tenham esse interesse.

Nossa intenção é apenas produzir narrativas a partir de outras narrativas, criando, como já dito, espaços de ficção e não de representação, fazendo valer a dimensão de mobilidade das memórias-narrativas, onde “[...] os detalhes não são nunca o que são: nem objetos, pois escapam como tais; nem fragmentos, pois não se bastam; nem estáveis, pois cada lembrança os altera" (Certeau, 1994, p. 165).

\section{Os anos iniciais, o convívio familiar, o início da formação e a experiência da guerra}

Jean-Michel-Emmanuel de la Barge de Certeau, ou Michel de Certeau, nasceu no dia 17 de maio de 1925, em Chambéry, comuna francesa, capital do Departamento de Savoie, na Região Rhône-Alpes. Seus pais, Antoinette de Tardy de Montravel e Hubert de la Barge de Certeau, tiveram quatro filhos - três 
homens e uma mulher, sendo Michel o primogênito. Como informam as biografias, Certeau cresceu no seio de uma família da petite noblesse de Savoie, detentora de propriedades rurais, em um contexto fortemente marcado pela religiosidade católica. Seu pai era engenheiro; sua mãe, órfã desde pequena, tinha um único irmão, que era monge beneditino.

O cotidiano da infância de Certeau foi marcado por encontros no verão de toda a família na casa de campo perto de Saint-Pierre d'Albigny (Savoie), cujas lembranças traziam, nas palavras de Giard (2006, p. 1), “[...] um profundo sentimento de Certeau pela velha casa da família, pela região montanhosa e pelos dias felizes de suas aventuras infantis com seus irmãos". Como a fazenda de seus pais era administrada por caseiros, esses encontros acabavam reunindo os filhos das duas famílias na realização das tarefas do campo, bem como nos momentos de lazer ao ar livre que aconteciam em meio a uma atmosfera de intimidade, respeito mútuo e distância social, tendo em vista as tradições da sociedade francesa da época.

Certeau se dedicou desde muito cedo à leitura, tendo sido formado com base em um currículo bem estruturado da escola francesa de ensino secundário, cujas principais matérias eram o grego, o latim e a filosofia alemã. Iniciou seus estudos no colégio religioso de Notre-Dame de La Villette, onde permaneceu como pensionista até a classe retórica em 1940-41, com 16 anos. Durante os anos de 1942 e 1943, ainda em regime de pensionato, frequentou a instituição Sainte-Marie, colégio Marista de La Seyne-sur-Mer, onde finalizou o curso secundário e se tornou membro da juventude estudante católica (Vidal, 2005).

Ao final de sua adolescência, Certeau sentiu-se atraído pela vida monástica cartusiana, que combinava vida solitária com um mínimo contato com a comunidade, lembrando sem- 
pre aos seus amigos que a ordem surgiu após um humilde retiro nos Alpes. Assim, no decorrer de sua formação também se tornou seminarista católico, sentindo-se convocado a servir a Deus ao mesmo tempo em que buscava um modo de vida e de comunidade capaz de satisfazer seus desejos (Giard, 2006).

Ainda na adolescência, Certeau conviveu com a ocupação da França pelas tropas alemãs em 1940. Ele tinha apenas 15 anos quando viu e sentiu toda a sua geração sofrer "[...] a experiência dolorosa da derrota e da resignação dos pais" (Vidal, 2005 , p. 259), o que não o impediu de participar como mensageiro de um grupo de resistência ao nazismo.

\section{A busca por outras experiências de vida e as formaçōes em Grenoble, Paris e Lyon}

Com o fim do período sombrio da segunda grande guerra que, como já destacado, privou sua geração da liberdade comum a todo adolescente, Certeau sentiu necessidade de, como ele mesmo dizia, buscar ar fresco, longe de sua região provinciana. Essa busca visceral por outras paisagens e sentidos de vida o levou a realizar longas e solitárias viagens de bicicleta pela França, experimentando viver os acontecimentos cotidianos da maneira mais simples possível, sem nenhum objetivo ou itinerário pré-definido “[...] dormindo sob as estrelas, comendo refeições leves, bebendo água de fontes, lendo e tomando nota de livros, meditando e parando aqui e ali, na praça de algum remoto vilarejo, por causa da luz, da musicalidade das vozes ou do silêncio de um dia quente" (Giard, 2006, p. 1).

As situações vividas por Certeau nessas viagens aliadas às experiências que teve da guerra influenciaram fortemente sua visão sobre a fragilidade da condição humana e a efemeridade da vida, levando-o a um exercício de busca por conhecer e educar seu corpo e sua mente para usar, da melhor maneira 
possível, o tempo e a energia de que dispunha. Essa disciplina do corpo-mente fez com que Certeau resistisse a longas horas de trabalho, dia e noite, bem como a inúmeras viagens e tarefas. Entretanto, mesmo com todos os seus dias cheios de compromissos e de atividades, "[...] sempre achava tempo para receber visitas, ouvir suas perguntas, ler seus trabalhos, como se fossem mensageiros pelos quais esperava" (Giard, 2006, p. 2).

Após finalizar o ensino secundário e partir para viver novos ares - fato que, para alguns biógrafos, seria a marca de uma tradição do peregrinatio academica, isto é, da prática do aluno viajar por diferentes lugares em busca de grandes mestres -, Certeau teve a oportunidade, no período de 1943 a 1950, de estudar em diferentes universidades como Grenoble, Paris e Lyon. Obteve uma consistente formação nos clássicos, com bacharelado em Latim, Grego, Alemão e Filosofia e, ainda, licenciando-se em Letras Clássicas, com ênfase em Grego e Filosofia.

Nos anos de 1943 e 1944, Certeau frequentou o curso de Letras da Universidade de Grenoble. A partir de outubro de 1944, ingressa no Séminaire des Messieurs de Saint-Sulpice em Issy-les-Moulineaux, subúrbio de Paris, uma instituição de orientação clássica e austera onde cursou, nos anos acadêmicos de 1944-45 e 1946-47, o ciclo filosófico. Para Vidal (2008, pp. 260-1), a partir dessa experiência de formação e, ainda, “[...] estimulado pelo que no pós-guerra foi denominado de nova teologia, Certeau seguiu para o seminário universitário de Lyon para dar continuidade aos estudos, consagrando-se à teologia”.

Giard (2006) se refere à experiência de Certeau na universidade católica de Lyon destacando o forte programa de estudos bíblicos oferecido que incluía, por exemplo, o Velho Testamento Hebreu e o Novo Testamento Grego, além de filosofia acadêmica. A vocação e o desejo de Michel de Certeau de 
entrar para o sacerdócio foram confirmados em Lyon ao incluir, ao seu bacharelado de Filosofia, uma licenciatura em Teologia.

Além disso, o convívio na residência jesuítica de Fourvière possibilitou a Certeau conhecer inúmeros padres, entre eles o teólogo jesuíta Henri de Lubac, que viria a ser cardeal quando idoso, e que teve grande influência na sua decisão, no outono de 1950, de entrar para a Companhia de Jesus, tendo recebido sua tonsura ${ }^{1}$ em 1948, e a ordenação sacerdotal, em 31 de julho de $1956 .^{2}$

O cotidiano vivido em Fourvière possibilitou a Certeau compartilhar inúmeras experiências sobre acontecimentos políticos, mudanças sociais e debates intelectuais vividos por aqueles padres em diferentes lugares, como China, Américas, Madagascar e Oriente Médio. Para Vidal (2005, p. 261), “[...] foi Lubac e o desejo de ser enviado em missão à China que fizeram Certeau, àquele momento já padre, recomeçar sua formação na ordem jesuíta, partindo para o noviciado em 1950, em Laval".

Para Giard (2006), o momento mais forte da formação de Certeau aconteceu nos anos de 1953-54, no famoso Seminário Jesuíta Les Fontaines, Chantilly, por ocasião de sua admissão como um dos membros mais avançados do grupo no programa especial de um ano dedicado à filosofia de Hegel. Como nos informa ainda a autora (p. 3), "[...] os poucos felizardos passaram um ano inteiro, seis horas por dia, em dedicada leitura sobre Hegel, lido em alemão sob a orientação do Padre Joseph Gauvin.

1 A tonsura é uma cerimônia religiosa em que o bispo dá um corte no cabelo do ordinando ao conferir-lhe o primeiro grau de Ordem no clero, chamado também de "prima tonsura".

2 "Nesse meio tempo, havia completado a série necessária da experimenta Jesuíta, um serviço a doentes num hospital, catequese e pregação numa paróquia, etc., dentre os quais estava um ano no cargo de professor numa escola jesuíta. Seu cargo era em filosofia para alunos equivalentes à $12^{\text {a }}$ série em Britanny em Vannes, Morbihan, em 1954-1955”. (Giard, 2006, p. 3). 
Mais tarde, Certeau declararia sua gratidão a Gauvin, que havia lhe ensinado tanto".

\section{O doutorado na Universidade de Paris V, suas viagens ao Brasil em maio de 1968}

Como pudemos notar, a certeza de Certeau em ingressar para a vida e a carreira eclesiásticas, alimentada desde sua adolescência e fortemente influenciada por Henri de Lubac, se confirmou. Nesse sentido, apesar de sua sólida formação universitária, não foi dada a Certeau nenhuma regalia ou facilidade, sendo submetido a um longo treinamento do scholasticus approbatus. Como informa Giard (2006, p. 3), “[...] muitos anos após seus estudos, alguns dos seus companheiros ainda lembravam o quanto seu brilhantismo era assustador"; muito embora nunca tivesse sido arrogante ou mesmo competitivo.

Em suas análises, Quadros (2002) infere que as formações religiosas exigentes pelas quais passou, aliadas ao apreço que tinha pelos estudos, levaram Certeau a seguir a carreira universitária, tendo ingressado no doutorado em Ciências da Religião na Universidade de Paris V. A tese foi defendida em 1960, abordando Pierre Fabvre, o companheiro francês de S. Inácio de Loyola, e foi orientada pelo historiador e filólogo Jean Orcibal.

Ainda durante o doutorado, Certeau pôde cursar os seminários de Roland Mousnier, erudito historiador especializado na Idade Moderna, e de Alphonse Dupront, um dos poucos historiadores que buscavam construir uma nova abordagem da história religiosa que passasse pelo diálogo com a psicologia junguiana e a antropologia. Como entende Quadros (2002, p. 3), “[...] Na concepção de Dupront, uma boa compreensão das 
manifestações religiosas deve deixar o enfoque apenas objetivo para buscar a subjetividade".

Também foi na universidade de Paris V que Certeau se interessou pela psicanálise, tendo frequentado assiduamente os seminários de Jacques Lacan durante 16 anos, com quem teve uma amizade duradoura. "[...] Quando, em 1964, Lacan rompeu com outros psicanalistas e organizou a Escola Freudiana de Paris, Certeau achava-se dentre os fundadores" (Quadros, 2002, p.3).

Para Vidal (2005), a psicanálise dava a Certeau a possibilidade de compreender a experiência espiritual dos místicos sem encerrar a interpretação em uma explicação clínica, uma vez que se constituía como um espaço favorável, indefinido, sempre aberto às práticas de escuta do Outro. Como infere a autora (p. 261), a atração pelo Outro, pela alteridade, sempre foi uma das principais marcas da obra do autor, uma vez que "[...] A escuta de um sujeito aprendida a partir de um outro, de uma palavra que era a palavra do Outro, constituía-se em uma estrutura análoga à expressão da espiritualidade”.

Sua primeira viagem à América Latina aconteceu como representante da revista Études no congresso da Confederação Latino-Americana de Religião, ocorrido no Rio de Janeiro entre 27 de outubro a 6 de novembro de 1966. Como informa Vidal (2005, p. 263), “[...] Certeau ficou impressionado com as condições de vida da população pobre carioca, residente nas favelas que qualificou de 'banida da cidade resplandecente e, ao que tudo indica, da luz que envolve, à noite, o Cristo tão longe do Corcovado"'.

O interesse de Certeau pelo Brasil e pelo modo de vida dos brasileiros o levou a voltar ao Rio de Janeiro onde se dedicou a observar as práticas cotidianas de uma missão católica 
instalada na Favela dos Cabritos. ${ }^{3}$ Nessa mesma viagem, foi a Belo Horizonte, Mariana e Ouro Preto, por conta de seu interesse pela cultura popular brasileira. Vidal (2005, p. 264) relata que esse interesse fez com que solicitasse ser enviado em missão para o Brasil em 1968 e, mesmo não conseguindo, continuou sensível à situação política brasileira. “[...] Em artigo escrito para a revista Politique aujourd'hui, denunciou a prática de tortura, a perseguição a estudantes e professores universitários considerados pelo governo militar como subversivos e a invasão das universidades por policiais".

O posicionamento político de Certeau frente ao regime militar rendeu-lhe, como escreve Vidal (2005, p. 264), a proibição de viajar às terras brasileiras, o que ele conseguiu reverter com um passaporte com o sobrenome La Barge. Esta estratégia lhe permitiu, nas várias viagens que fez, conhecer melhor os territórios e as culturas brasileiras. ${ }^{4}$

A autora infere que as experiências vividas por Certeau no Brasil deixaram marcas no intelectual levando-o a fazer referência a alguns dos acontecimentos culturais presenciados por ele. Por exemplo, ao teorizar sobre as culturas populares no livro A invenção do cotidiano, Certeau (1994) descreve uma cami-

3 Fica entre os bairros de Copacabana e Lagoa, integrando o Parque Natural Municipal da Catacumba, que por sua vez faz parte da Área de Proteção Ambiental Morro dos Cabritos e Saudade. Na face sul, em Copacabana, existe uma comunidade que começou a se formar em 1926, quando imigrantes nordestinos se estabeleceram na subida do morro. Foi por causa desses primeiros moradores, que criavam cabras, que o morro ganhou o nome.

4 "Atento às manifestações do Nordeste brasileiro, participou com regularidade se seminários de pesquisa sobre linguagem popular e religião na cidade do Recife, a partir de 1973 [...]. Em Salvador, visitou um terreiro de candomblé. A resistência indígena à assimilação cultural também não passou despercebida ao autor que, destacando as estratégias não violentas de reapropriação, discorreu sobre a indianidade nos países latino-americanos (sic), citando o exemplo dos Bororós do Mato Grosso nos artigos reunidos em La prise de parole et autres écrits politiques." (Vidal, 2005, pp. 264-65). 
nhada feita durante a noite barulhenta de Salvador até a Igreja do Passo, sempre atento aos contrastes entre a poeira e o suor da cidade, os monumentos e os barulhos e vozerios vindos dos bairros antigos.

Toda essa atmosfera vivida por Certeau lhe sugeriu a existência de segredos silenciosos e monumentais que escapavam aos pesquisadores, embora estivessem ali, diante deles e de seus olhos. Também lhes escapava a língua popular, vinda de muito longe. A observação prolifera e tateia, mas seus segredos não se entregam. Trata-se de uma "arte" brasileira pensada como táticas de usos de seus praticantes, como formas de resistir aos sistemas. "[...] Nesses estratagemas de combatentes existe uma arte dos golpes, dos lances, um prazer em alterar as regras do espaço opressor. Destreza tática e alegria de uma tenacidade" (Certeau, 1994, p. 79).

Ao receber em 1967 um convite para integrar a revista Études, Certeau passa a morar em Paris e a escrever regularmente para esse periódico. No mesmo ano, sofre um acidente de automóvel no qual tem uma das vistas afetada e sua mãe vem a falecer. Foi ainda em 1967 que o autor conviveu com situação política do Chile. Como informa Giard (2006), Certeau possuía muitos amigos jesuítas cujo processo político ele acompanhava com atenção por conta de Salvador Allende. ${ }^{5} \mathrm{Na}$ manhã em que o golpe militar foi anunciado, Giard havia combinado trabalhar com ele, o que não aconteceu. "[...] Certeau veio ao nosso encontro com uma aparência sombria no rosto, dizendo: 'Vão matá-lo [Allende], e muitos outros em volta dele"' (Giard, 2006, p.3).

5 Salvador Allende Gossens foi um médico e político marxista chileno. Fundador do Partido Socialista, governou o Chile de 1970 a 1973, quando foi deposto por um golpe de estado liderado por seu chefe das Forças Armadas, Augusto Pinochet. 
A convivência de Certeau com os acontecimentos de Maio de 1968 representou, para alguns biógrafos, uma mudança na vida do autor ao projetá-lo para além dos muros eclesiásticos. Ao falar desse momento, Giard (In Certeau, 1994) é enfática ao observar que a fama de Certeau ultrapassou as fronteiras dos meios dos historiadores, recebendo convites de inúmeros círculos intelectuais de esquerda e do mais alto escalão administrativo.

Para ela, a notoriedade que conferiu a Certeau um novo papel social decorreu de sua surpreendente capacidade de analisar ao vivo um turbilhão de acontecimentos que caracterizavam um tempo de incertezas, propondo uma leitura inteligente, generosa e acolhedora das mudanças, livre do medo que paralisava muitos intelectuais daquela época. Nesse sentido, não buscou propor soluções, muito menos apresentar um diagnóstico definitivo sobre o futuro, mas, sobretudo, buscou entender o que estava acontecendo.

Ou seja, ao invés de se preocupar com a confusão dos discursos, as lamentações e as censuras Certeau indaga: "Esta ebulição, esta desordem de palavras e barricadas, essa revolta e tantas greves, o que dizem a respeito de uma sociedade, do que ela esconde e espera? Na brecha entre o dizer e o fazer Certeau não vê ameaças, mas uma possibilidade de futuro" (Giard, In Certeau, 1994, p. 12).

Para Giard, os acontecimentos ocorridos em maio de 1968 deixaram marcas definitivas na vida de Michel de Certeau, tocando-o profundamente e provocando nele uma ruptura instauradora, não no sentido de renegar sua vida anterior, mas pelo fato de ele canalizar seu trabalho para "[...] voltar a esta 'coisa' que aconteceu e compreender aquilo que o imprevisível nos ensinou a respeito de nós mesmos, ou seja, aquilo que, então, nos tornamos" (Giard, In Certeau, 1994, p. 12). 
Como é possível inferir a partir do pensamento da autora, essa busca por entender o que o imprevisível pode provocar em nossas vidas instiga Certeau a construir seu próprio caminho de pensamento, sua própria metodologia de pesquisa chegando a uma das questões fundamentais de sua teoria: como se cria! Com isso, o autor desloca a ideia de um consumo supostamente passivo e/ou alienado dos produtos que recebemos para o que ele chama de criação anônima, que insurge com a prática do desvio no uso que fazemos desses produtos. Como escreve Giard (In Certeau, 1994, p. 13), para Certeau faz-se necessário que nos interessemos pelas criações anônimas e que são perecíveis e não se capitalizam, ou em outras palavras, "[...] é preciso interessar-se não pelos produtos culturais oferecidos no mercado de bens, mas pelas operações de seus usuários; é mister ocupar-se com 'as maneiras diferentes de marcar socialmente o desvio operado num dado produto por uma prática”.

\section{Os anos finais}

No final de julho de 1985, Michel de Certeau recebeu um diagnóstico de câncer, o que não o impediu de continuar trabalhando e de ministrar seus últimos seminários até dezembro daquele mesmo ano, vindo a falecer em 9 de janeiro de 1986, em seu apartamento em Paris.

O período que antecedeu a morte de Certeau comprovou que seu maior excesso era seu hábito de trabalhar incessantemente, dedicando muitas horas de sua vida para a escrita de seus livros, manuscritos, palestras e trabalhos de amigos e alunos, ficando surpreso quando alguém não conseguia fazer o mesmo e pedia uma pausa ou adiamento. Mas, como atesta Giard (2006, p. 2), "logo depois, com um brilho de alegria nos olhos, dizia: 
'É uma ótima ideia, vamos parar por aqui, tenho outro trabalho para escrever para amanhã e corria para seu escritório".

A autora infere que esse ritmo acelerado segundo o qual Certeau trabalhava e pensava, provocou nele um hábito de, de modo geral, colocar em circulação uma primeira versão de seus escritos ainda em processo, os quais, posteriormente, ele revisava, expandia e finalmente transformava em capítulos de livros.

Como conclui Giard (2006, p. 5), "Não que ele não fosse capaz de elaborar longas obras, ou que sua mente não conseguisse trabalhar em um projeto longo. Esse modo de trabalhar veio, eu acho, de um sentimento interior de que o tempo era curto, de que a tarefa poderia ser interrompida a qualquer momento, e que o autor não seria capaz de finalizar sua obra".

Após sua morte, Marc Augé, Presidente da École des Hautes Études en Sciences Sociales, a mesma instituição onde Certeau ministrou seus últimos seminários, fez um preciso retrato do autor: "Era um intelecto sem medo, cansaço ou orgulho" (Giard, 2006).

6 "Eventos familiares reforçaram esse sentimento: seu irmão Jean (mais novo que ele dez meses) morreu com vinte e poucos anos, sua irmã MarieAmélie, com trinta e poucos, e ele perdeu um olho em um acidente de carro (agosto de 1967), perto de Chambéry, no qual morreu sua mãe (seu pai, que dirigia o carro saiu ileso). Ao lembrar-se dos dias negros passados no hospital, após o acidente (os médicos não sabiam dizer se ele sobreviveria), ele dizia: 'Eu temia que tivesse virado um idiota e ninguém queria me contar a verdade"' (Giard, 2006, p. 5). 


\section{CAPÍTULO 2}

\section{A crítica à epistemologia da ciência e a aposta na atitude ético-estética em pesquisa}

O caminho técnico a percorrer consiste, em primeira aproximação, em reconduzir, as práticas e as línguas científicas para seu país de origem, a everyday life, a vida cotidiana. Este retorno, hoje sempre mais insistente, tem o caráter paradoxal de ser também um exílio em relação às disciplinas cujo rigor se mede pela estrita definição de seus limites. Desde que a cientificidade se atribuiu lugares próprios e apropriáveis por projetos racionais capazes de colocar zombeteiramente os seus modos de proceder, os seus objetos formais e as condições de sua falsificação, desde que ela se fundou como uma pluralidade de campos limitados e distintos, em suma, desde que não é mais do tipo teológico, a ciência constituiu o todo como o seu resto, e este resto se tornou o que agora denominamos a cultura (Certeau, 1994, pp. 64-5).

Em sua empreitada para formular uma teoria das práticas cotidianas, Michel de Certeau teceu, com seus próprios relatos e gestos em pesquisa, modalidades de ações que se inscrevem entre as lógicas operatórias das artes de dizer e das artes de fazer que se forjam com a cultura ordinária, sobre as quais ele se debruçou com afinco e rigor engajado por muitos anos, especialmente entre maio de 1968 e janeiro de 1986, ano de sua morte.

Em sua trajetória acadêmica, Certeau não só realizou com suas palavras e com seus atos uma crítica à epistemologia da História que se tornou hegemônica em sua época, e por ex- 
tensão das Ciências Sociais e Humanas, como fabricou astuciosamente, movido por sua tenacidade, inventividade e inconformismo, maneiras de fazer e de dizer a ciência que, na contingência das determinações institucionais, se insinuam tacitamente como um estilo de invenções técnicas e de resistência moral, por meio do qual "uma ordem é exercida como uma arte", ou seja, ela é, ao mesmo tempo, "exercida e burlada".

Certeau transitou, sem pedir licença, por diferentes instituições sociais, como Universidade, Igreja e Estado, e por diferentes disciplinas científicas, como Teologia, História, Sociologia, Antropologia, Filosofia, Linguística e Psicanálise, atravessando e, às vezes, se instalando nas fronteiras entre esses campos de saberesfazeres. Tais gestos de deslocamento e de hibridação, próprios a quem nunca se identificou totalmente com um lugar determinado, eram movidos pela necessidade que ele tinha de buscar um tratamento que considerasse satisfatório para os objetos de pesquisa que formulou, para as questões que produziu, para as problematizações que inventou.

Tratava-se de escapar da circunscrição de um lugar próprio e dos limites que, por meio desta, são impostos ao pensamento e à ação. Os múltiplos atravessamentos institucionais e disciplinares lhe possibilitaram, além de abertura e movimento, uma interlocução com teóricos de vários campos do conhecimento (Freud, Lacan, Wittgenstein, Lévi-Strauss, Bourdieu e Foucault, entre outros) e um entrecruzamento de métodos que operacionalizaram a criação de instrumentos apropriados à análise das formalidades das práticas cotidianas.

Certeau vivenciou, na sua experiência acadêmica, o que ele próprio denominou de "liberdade gazeteira das práticas": jogou com a normatividade imposta ao trabalho científico, subvertendo-a; fez usos de métodos, técnicas, pressupostos e rotinas institucionais para praticar a ciência "diferentemente", de 
uma maneira informada por seus próprios interesses e desejos; e, ainda, no diálogo com outros teóricos, fez-lhe filhos pelas costas, aliás, filhos monstruosos, ao modo que, segundo Deleuze, teria feito Nietzsche em seus encontros com outros pensadores.

Filhos pelas costas é ele quem faz. Ele dá um gosto perverso (que nem Marx nem Freud jamais deram a ninguém, ao contrário): o gosto para cada um dizer coisas simples em nome próprio, de falar por afectos [sic], intensidades, experiências, experimentações. Dizer algo em nome próprio é muito curioso, pois não é em absoluto quando nos tomamos por um eu, por uma pessoa ou um sujeito que falamos em nosso nome. Ao contrário, um indivíduo adquire um verdadeiro nome próprio ao cabo do mais severo exercício de despersonalização, quando se abre às multiplicidades que o atravessam de ponta a ponta, às intensidades que o percorrem. $\mathrm{O}$ nome como apreensão instantânea de uma tal multiplicidade intensiva é o oposto da despersonalização operada pela história da filosofia, uma despersonalização de amor e não de submissão. Falamos do fundo daquilo que não sabemos, do fundo de nosso próprio subdesenvolvimento. Tornamo-nos um conjunto de singularidades soltas, de nomes, sobrenomes, unhas, animais, pequenos acontecimentos: ao contrário de uma vedete (Deleuze, 1992, p. 15).

O modo operacional dessa interlocução consistia, então, em extrair do pensamento desses autores conceitos e gestos que eles insinuaram ou tornaram possíveis, embora não tenham sido explicitados ou desenvolvidos. Certeau buscava perceber, principalmente, através dos relatos de pesquisas produzidos por esses cientistas, os procedimentos realizados em sua execução e que levaram a determinados resultados e não outros, fazendo, com a análise dessas maneiras de fazer e de dizer, uma críti- 
ca. Ao mesmo tempo, também procurava uma apropriação que produzisse diferença na produção científica e que fosse compromissada com a afirmação da criação de conhecimentos e modos de conhecer nos demais domínios da vida cotidiana.

Os acontecimentos de Maio de 1968 em Paris marcaram o jesuíta e historiador da mística religiosa nos séculos XVI e XVII, provocando uma ruptura instauradora da necessidade de compreender a cultura de sua época. A necessidade de se voltar para o que o "imprevisível poderia nos ensinar" sobre nós mesmos forjou a formulação de um novo objeto de pesquisa. No exercício obstinado para compreender aquele momento, ele passou a se interessar não pelos produtos culturais, como faziam outros pesquisadores à época, mas pelas operações de usuários desses produtos, ou seja, "pelas maneiras diferentes de marcar socialmente o desvio num dado operado por uma prática" (Certeau, 1994, p. 13). E foi nessa mesma lógica que se engendraram, conforme o nosso modo certeauniano de ver, as práticas acadêmicas e científicas desse autor.

Tomou para si, desde então, a tarefa de afirmar a vida cotidiana como espaçotempo de criação permanente de conhecimentos e de modos de conhecer, de existir e de viver com outros, depositando sua confiança na inteligência e na inventividade dos homens e mulheres comuns, praticantes da cultura e usuários de artefatos que não foram produzidos por eles, mas que lhes são impostos. Ao invés de submissão, conformismo, alienação e passividade, ele enxergou nessas operações de praticantes mecanismos de resistência forjados com os usos que fazem do que lhes é imposto: uma produção secundária, clandestina e silenciosa que pode constituir microliberdades e, no limite, redes de antidisciplina.

Diante dessa tarefa, Michel de Certeau operou um duplo mecanismo para indicar o cotidiano como lugar de criação, in- 
venção e antidisciplina. Em sua empreitada teórica, ele foi desconstruindo, com sua crítica, a produção e a operacionalidade de lugares que se pretendem como não cotidianos (como a universidade e os laboratórios de pesquisa). Foi desnaturalizando as operações de poder que buscavam produzi-los como tal, e, ao mesmo tempo, foi criando métodos para capturar, examinar, descrever e dar visibilidade às práticas do dia a dia dos homens e mulheres comuns e ao que eles fabricam e criam com os usos que fazem das mercadorias, das normas, das leis, dos conhecimentos e das significações hegemônicos que lhes são impostos e/ou apresentados como dados irrefutáveis.

Com o propósito de melhor destacar esse duplo mecanismo, que atravessa de ponta a ponta as obras do autor mais divulgadas em nosso país (A escrita da história, A cultura no plural, A invenção do cotidiano [volumes 1 e 2] e História e psicanálise), ainda que de forma mais explícita ou implícita aqui e ali, enfatizaremos alguns aspectos da crítica à epistemologia das Ciências Sociais e Humanas. Destacaremos alguns procedimentos realizados pelo próprio Michel de Certeau e seu grupo no trabalho de pesquisa para abordar as práticas cotidianas e apresentaremos algumas considerações sobre o ensino nas universidades no contexto da cultura de massa.

\section{Ciência como ficção sociocultural que fabrica o real pretensamente representado}

No primeiro volume de $A$ invenção do cotidiano (1994), Michel de Certeau nos ensinou que as práticas ordinárias, as experiências singulares, as frequentações, as solidariedades, os enfrentamentos, as tensões, os consensos, as rotinas produtivas e as relações de forças organizam os diferentes espaçostempos em que vivemos, ensinamosaprendemos e pesquisamos, constituin- 
do não apenas a "paisagem de uma pesquisa" e "uma maneira de caminhar", como também o que vai sendo considerado como científico, educativo e cultural, entre outros domínios de nossa existência. As maneiras de fazer constituem, nessa perspectiva, processos mudos de apropriação que organizam a ordenação sociopolítica e instauram um presente relativo a um determinado momento e lugar, estabelecendo contato com outro numa rede de relações.

A ciência, como instituição, também é uma produção sociocultural, ainda que regida por técnicas específicas e lógicas operacionais próprias sob a égide de poderes econômicos e autoridades simbólicas. Fazer pesquisa também é uma prática cotidiana para aqueles que escolheram ou foram escolhidos por esse ofício e que ocupam, alternadamente, posições diversas nas relações de poder e de trabalho forjadas nos laboratórios e nas academias científicas. E, assim sendo, existem mil maneiras, autorizadas e não autorizadas, mas sempre disputadas, de se fazer ciência. Porém, conforme nos mostrou Certeau (1994, 1995, 1996, 2006, 2011), nenhuma delas - mesmo aquelas que tentam se enquadrar nos critérios de verdade, neutralidade, objetividade, universalidade e racionalidade, inventados com o paradigma tecnicista-cientificista forjado na modernidade histórica ocidental - conseguiu realizar, com as práticas de conceber e expressar conhecimentos, a fronteira que se tentou construir entre a ciência e "todo o seu resto".

$\mathrm{Na}$ crítica que fez à historiografia, e que aqui nos apropriamos e estendemos aos modos operacionais de produção e divulgação de conhecimentos nas Ciências Sociais e Humanas, Certeau (2011), buscando desconstruir a possibilidade de apreensão total do real pesquisado e problematizando os efeitos criados pelos discursos que insistem em afirmar que falam em 
nome desse real, assinala quatro modos de funcionamento possíveis da ficção na produção científica.

O primeiro deles diz respeito ao próprio estatuto da ciência, legitimado não pelos resultados obtidos e comprovados com suas pesquisas, mas sim por meio do distanciamento que instaura em relação ao dizer e ao crer comuns. Essa distância, criada por múltiplos mecanismos, instala uma diferença que credencia a ciência ao distingui-la do discurso ordinário. Nesse modo de funcionamento da ficção na ciência, a verdade é produzida pela identificação do erro nas narrativas não científicas. Trata-se, portanto, de um trabalho de falsificação efetuado pela ciência, por meio do qual ela institui a ficção como um elemento da cultura. Nesse modo de produção da diferença entre a ciência e todo o seu resto, a ficção opera como sinal do falso.

O segundo modo de funcionamento da ficção na ciência articula ficção e realidade. Nessa operação, que resulta de procedimentos de análise e interpretação, o discurso técnico ao identificar os erros característicos da ficção autoriza-se a falar em nome do real. A ficção torna-se, então, sinal do irreal. O procedimento, segundo Certeau (2011, p. 46), é simples:

[...] ao comprovar os erros, o discurso leva a considerar como real o que lhe é contrário. Apesar de ser logicamente ilegítimo, o procedimento funciona ('marche') e 'leva na conversa' ('fait marcher'). Desde então, a ficção é transferida para o lado do irreal, enquanto o discurso tecnicamente armado para designar o erro está afetado pelo privilégio suplementar de representar o real.

Em uma terceira circunstância, Certeau assinala que a ficção se encontra também no próprio campo da ciência, no cerne de sua produção, não cabendo mais indagar o que as linguagens científicas exprimem ou representam, mas o que elas organizam e tornam possível. Diz respeito, portanto, ao que é possível criar 
e transformar com a ciência. Nesse modo de funcionamento, a ficção é o signo do artefato científico.

Por fim, no quarto modo de funcionamento apontado pelo autor, a ciência articula a ficção e o limpo. Nessa perspectiva, a ficção, acusada de não se constituir em um discurso unívoco, "de carecer de 'limpeza' ['propreté'] científica", torna-se sinal de uma deriva semântica, produzindo efeitos de sentido que não podem ser circunscritos nem controlados.

Mas, enfim, por que voltar a atenção para os modos de funcionamento da ficção na ciência? De que forma essa problematização pode nos ajudar a questionar, desnaturalizar e reinventar as epistemologias dominantes? Em primeiro lugar, talvez, porque para o autor (2011, p. 48)a ficção "é um discurso que dá forma ('informe') ao real, sem qualquer pretensão de representá-lo ou ser informado por ele", o que faria dessa modalidade narrativa menos um objeto de estudo e mais um modelo possível e alternativo para os relatos científicos que ainda insistem em falar com objetividade e neutralidade, em nome da verdade e do real. Pois, segundo Certeau (2011, p. 53):

A narrativa que fala em nome do real é imperativa; ela 'faz conhecer', à maneira como se dá uma ordem. Nesse aspecto, a atualidade (o real cotidiano) exerce um papel semelhante ao que a divindade desempenhava outrora: os padres, as testemunhas ou os ministros da atualidade fazem com que ela fale para dar ordens em seu nome. Certamente, 'fazer falar' o real já não é revelar as vontades secretas de um Autor; daqui em diante, algarismos e dados fizeram as vezes desses segredos 'revelados'. No entanto, a estrutura permanece a mesma: ela consiste em ditar, interminavelmente, em nome do 'real', o que deve ser dito, o que se deve crer e o que deve ser feito. E o que opor a 'fatos'? A lei que relata em dados e algarismos (ou seja, em termos fabricados por técnicos, mas apresentados como manifestação derradeira da au- 
toridade, o Real) constitui nossa ortodoxia, um imenso discurso de ordem.

Essa questão é ainda mais relevante quando entendemos que a narrativa que afirma falar em nome do real é, muitas vezes, eficaz, transformando e regulando o espaço social. "Ao pretender relatar o real ela o fabrica. Ela é performática. Ela torna crível o que diz e faz agir por essa razão" (Certeau, 2011, p. 53).

Em segundo lugar, a atenção à ficção em suas articulações com a ciência torna-se importante na medida em que as representações da realidade produzidas pelas operações científicas, muitas vezes, buscam camuflar as condições reais de sua produção, ou seja, buscam ocultar que são produtos de um meio, de um poder, de uma lógica, de uma técnica, enfim, das rotinas produtivas instituídas por uma comunidade científica.

No entanto, essa comunidade é também uma usina, distribuída em cadeias de montagem, submetida a exigências orçamentárias, associada, portanto, a políticas e às condicionantes crescentes de um aparato sofisticado (infraestruturas arquivísticas, computadores, modalidades de edição, etc.) ela é determinada por um recrutamento social bastante restrito e homogêneo; orientada por esquemas ou postulados socioculturais que impõem tal recrutamento, a prioridade/recursos afetados às pesquisas, os interesses do orientador/patrocinador, as correntes da época, etc. Além disso, sua organização interna baseia-se na divisão do trabalho; ela tem seus diretores, sua aristocracia, seus 'chefes de trabalhos' (frequentemente proletários das pesquisas decididas pelos diretores de departamento), suas técnicas, seus redatores mal remunerados e seus encarregados da manutenção (Certeau, 2011, p. 50). 
Ainda que ele estivesse se referindo à realidade das rotinas produtivas nas instituições de pesquisa francesas no final do século XX, muitas dessas contingências, determinações, constrangimentos e modos operacionais assemelham-se aos que experimentamos atualmente em nossas universidades no Brasil. Ontem e hoje, lá e aqui, "o elemento excluído do discurso é justamente a garantia da coesão prática do grupo" (Certeau, 2011, p. 54). Da mesma forma, é em meio a essas contingências, determinações e constrangimentos que inventamos nossos modos de fazer pesquisa, produzindo, com nossas práticas, desvios e diferenças em relação ao que está posto.

Nesse sentido, Certeau (2006) nos dá algumas pistas de gestos possíveis para uma repolitização das Ciências Sociais e Humanas. O primeiro deles diz respeito à necessidade de considerarmos a localização onde se engendra a produção, ou seja, de especificarmos a particularidade do lugar (social e científico) de onde falamos, tendo em mente que tal localização configura temas, interesses e pontos de vista. Trata-se ainda de sublinhar a singularidade de cada análise e de questionar sistematizações globalizantes.

Outro gesto ético e político indicado pelo autor é a atenção ao ato produtor da ciência, o que implica manifestar as regras de produção, considerar o domínio em que o trabalho se realiza, assumir os limites e as possibilidades de transformação do lugar institucional, confrontar com a alteridade e se abrir às multiplicidades. Trata-se, com esse gesto, de assumir o lugar em que a produção científica se articula e que a torna possível, sem, no entanto, se reduzir às suas determinações. 


\section{Os limites impostos pela estatística às pesquisas das/com as práticas cotidianas}

Considerando que a produção da ciência diz respeito a um poder, um meio, uma técnica e uma tecnologia, Certeau (2011) destaca que a informática abriu a possibilidade para as pesquisas quantitativas. Graças à informática, assegura, os pesquisadores tornaram-se capazes de construir regularidades e periodicidades, enchendo suas representações de algarismos e "garantias de objetividade".

As condições circunstanciais para as operações estatísticas, segundo o autor, remetem a uma tripla determinação histórica: a primeira, de natureza técnica, se engendra com o progresso das matemáticas e da abordagem quantitativa da natureza; a segunda, sociopolítica, surge com um modo de organização administrativa que uniformiza o território fornecendo um modelo para a gestão geral dos cidadãos; e a terceira, de natureza ideológica, emerge com o surgimento de uma elite convencida do seu poder em garantir uma racionalização da sociedade. A historicização da estatística realizada por Certeau tem por função oferecer uma contrapartida à ambição de matematizar a ciência. Como defende o autor $(2011$, p. 55):

Nessa análise da sociedade baseada na matemática, é preciso, com efeito, sublinhar: $1^{\circ}$ sua relação com as condições de operacionalidade históricas; $2^{\circ}$ as reduções técnicas que ela impõe e, portanto, a relação entre o que ela aborda e o que deixa fora; por último, $3^{\circ}$ seu funcionamento efetivo no campo historiográfico, ou seja, o modo de recuperação, ou de sua assimilação, pela disciplina que, supostamente, é transformada por ela. Eis outra forma de assistir ao retorno da ficção a uma prática científica. 
Apesar de não desprezar nem as possibilidades oferecidas pela estatística quando combinada com outros tipos de análise e nem o "efeito de cientificidade" que ela produz com o tratamento quantitativo de dados, Michel de Certeau percebe os limites que esse tipo de sondagem implica e a afasta de seu projeto. A sondagem estatística, devido aos seus procedimentos próprios, deixa escapar o que mais interessa a esse autor - isto é, as operações efetuadas nas/com as práticas cotidianas, suas singularidades, suas lógicas e suas trajetórias.

Mesmo a estatística praticamente não leva isso em conta, pois ela se contenta em classificar, calcular e tabular as unidades 'léxicas', de que compõem essas trajetórias, mas às quais não se reduzem, e em fazê-lo em função de categorias e taxionomias que lhe são próprias. Ela consegue captar o material dessas práticas, e não sua forma; ela baliza os elementos utilizados e não o 'fraseado' devido à bricolagem, à inventividade 'artesanal', à discursividade que combinam estes elementos, todos recebidos, e de cor indefinida. Decompondo essas 'vagabundagens' eficazes em unidades que ela mesma define, recompondo, segundo seus códigos os resultados dessas montagens, a enquete estatística só 'encontra' o homogêneo (Certeau, 1994, pp. 45-6).

A estatística, em função dos seus modos de proceder para criar uma representação do real, reproduz o sistema ao qual pertence, conforme assinalou Certeau (1994, p. 46), deixando "de fora do seu campo a proliferação das histórias e operações heterogêneas que compõem os patchworks cotidianos". Tendo em vista a ultrapassagem da clivagem que organiza a modernidade, recortando a produção do conhecimento em "insularidades científicas" dispostas a conquistar todo o "seu resto", Michel de Certeau indica que a insinuação do ordinário em campos científicos constituídos pode produzir erosão em um corpo de 
técnicas de análise, criar aberturas, indicar deslocamentos e reorganizar o lugar onde se produz o discurso.

As maneiras de fazer ciência, como as nossas próprias experiências sugerem, se inscrevem em territórios movediços, nos quais as práticas cotidianas, por meio de gestos e relatos, organizam os campos, os lugares de saber/poder e o estatuto das ciências. Essas operações de praticantes podem promover tanto ajuste e submissão à lógica hegemônica em determinado espaçotempo, como engendrar desvios e outros caminhos possíveis, e, desse modo, constituir um complexo e heterogêneo movimento antidisciplina, ou melhor, antidisciplinarização dos conhecimentos, valores e interesses em favor da afirmação da potência criadora da vida de todo dia, em todas as suas dimensões.

\section{Caminhos teórico-metodológicos possíveis para uma atitude ético-estética em pesquisa}

O caminhar de uma análise inscreve seus passos, regulares ou ziguezagueantes, em cima de um terreno habitado há muito tempo. Somente algumas dessas presenças me são conhecidas. Muitas, sem dúvida mais determinantes, continuam implícitas - postulados ou dados estratificados nesta paisagem que é memória e palimpsesto. Que dizer desta história muda? Ao menos, indicando os sítios onde a questão das práticas cotidianas foi articulada, vou marcar já as dívidas e também as diferenças que possibilitaram um trabalho nestes lugares (Certeau, 1994, p. 35).

Um gesto ético-estético de Certeau marca uma arte de fazer e uma arte de dizer em ciência forjadas com as suas práticas. Com tal gesto, relatado na abertura do volume um de $A$ invenção do cotidiano, ele apresenta a "paisagem de uma pesquisa" e "uma 
maneira de caminhar", assumindo a sua relação com lugares institucionais já instituídos e com uma produção científica que articula a questão que lhe interessa e antecede o seu trabalho.

Ao mesmo tempo, anuncia que vai demarcar as diferenças que produziu em relação ao já conhecido e que possibilitaram a realização de sua pesquisa nesses mesmos lugares. Tal gesto ético-estético, que remete a uma escolha implicada com o cuidado com os outros e a uma atitude de criação permanente, produz também uma abertura política ao afirmar que é possível fazer diferente, sem reduzir o trabalho científico aos constrangimentos exercidos pelo já dito, pelas regras da instituição, pelo mercado e pelas estruturas da administração político-econômica.

Ao tecer os passos que instituíram os caminhos a serem trilhados em sua pesquisa, Certeau, conforme seu próprio relato, começou por delimitar um campo - no caso, as práticas cotidianas - e instituir, por meio de sondagens e hipóteses, algumas possibilidades para a análise. Nessa empreitada, ele elaborou hipóteses sobre os modos operacionais e as lógicas das práticas ordinárias - ou seriam apostas na sua potência? - e articulou questões teóricas, métodos, categorias e pontos de vista para dialogar com o que já havia sido pensado a respeito, fazendo usos de conceitos e procedimentos para formular seu próprio repertório e modos de ver a questão.

O percurso metodológico realizado ou relatado por Certeau na execução desse trabalho, resultando no primeiro volume de $A$ invenção do cotidiano, consistiu, principalmente, em alternar a análise descritiva de algumas maneiras de fazer selecionadas (ler, habitar, narrar) com usos de uma "literatura científica suscetível de fornecer hipóteses que permitam levar a sério a lógica desse pensamento que não se pensa” (Certeau, 1994, pp. 42-3).

O que é interessante ressaltar nas interlocuções que Certeau criou com teóricos que o antecederam e também com pensadores a ele contemporâneos, é a atenção dada, não aos 
conteúdos comunicados, mas aos modos de fazer e relatar a pesquisa, a partir dos quais estipulou limites e possibilidades teórico-metodológicas postas à fabricação de uma epistemologia das práticas.

Com Freud e Wittgenstein, ele pensou a tessitura do ordinário por, entre e pela linguagem. Em O homem sem qualidades, refletiu com Freud sobre o lugar da linguagem ordinária na organização da atividade significante comum, discutiu o lugar de invenção da ciência e do sujeito e apontou a ultrapassagem das fronteiras constituídas que foi operada pela insinuação do ordinário na narratividade científica.

Com os usos que fez da filosofia da linguagem de Wittgenstein, interrogou a partilha entre as discursividades reguladoras das especializações e, ao mesmo tempo, constatou que a linguagem não pode constituir-se objeto de um discurso pelo fato de que "nenhum discurso pode 'sair dela' e colocar-se à distância para observá-la e dizer o seu sentido" (Certeau, 1994, p. 69). Nessa perspectiva, a análise da linguagem, afirmou, será sempre um exame interno.

\begin{abstract}
Abordar a linguagem 'na' linguagem ordinária, sem poder 'dominá-la com o olhar', sem visibilidade a partir de um ponto distante, quer dizer apreendê-la como um conjunto de práticas onde a própria pessoa do analisador se acha implicada e pelas quais a prosa do mundo opera (Certeau, 1994, p. 71).
\end{abstract}

Para além das e concomitantemente às formulações sobre a insinuação do ordinário na ciência, Certeau realizou uma observação e uma descrição rigorosa de algumas práticas cotidianas selecionadas, desenvolvendo, à medida que sentiu necessidade, conceitos que tornaram possíveis a análise de suas lógicas operatórias e a fabricação de narrativas que as colocassem no cerne da 
constituição do social. Tais conceitos e lógicas serão detalhadas em outros capítulos e por isso não vamos abordá-las aqui.

Em outro gesto, que nós consideramos ético-político, Michel de Certeau estabeleceu uma interlocução com Foucault e Bourdieu com o propósito de situar seu estudo em uma geografia da pesquisa a ele contemporânea. $\mathrm{O}$ que está em jogo nessa atitude é o estatuto da análise e a sua relação com o objeto formulado. Para o autor, os objetos de uma pesquisa resultam de seu aporte num campo onde ela se tornou possível, remetendo "a uma rede de intercâmbios profissionais e textuais" (Certeau, 1994, p. 109). Assim, como analisa o autor (p. 110):

Ao 'esquecer' o trabalho coletivo no qual se inscreve, ao isolar sua gênese histórica e objeto de seu discurso, um 'autor' pratica portanto a denegação de sua situação real. Ele cria a ficção de um lugar próprio. Malgrado as ideologias contrárias de que pode ser acompanhado, $\mathrm{o}$ ato de isolar a relação sujeito-objeto ou a relação discurso-objeto é a abstração que gera uma simulação de 'autor'. Esse ato apaga a situação de pertença de uma pesquisa a uma rede [...]. Um discurso manterá portanto uma marca de cientificidade explicitando as condições e as regras de produção e, em primeiro lugar, as relações de onde nasce.

Tais considerações levam à dívida assumida não como empréstimo ou agradecimento, mas como um elemento de qualquer discurso novo. Em Foucault, Certeau enxergou as novas perspectivas que este abriu para a análise das práticas, às quais foi possível acrescentar algumas questões relativas aos interesses da pesquisa sobre as práticas ordinárias. Tais perspectivas remetem à análise dos procedimentos que formam o tecido social em determinados espaçostempos e possibilitaram a Certeau (1994, p. 115) estabelecer que: 
Uma sociedade seria composta de certas práticas exorbitadas, organizadoras de suas instituições normativas, $e$ de outras práticas, sem-número, que ficaram como 'menores', sempre no entanto presentes, embora não organizadoras de um discurso e conservando as primícias ou os restos de hipóteses (institucionais, científicas), diferentes para esta sociedade ou para outras. É nesta múltipla e silenciosa 'reserva' de procedimentos que as práticas 'consumidoras' deveriam ser procuradas com a dupla característica detectada por Foucault, de poder, segundo modos ora minúsculos, ora majoritários, organizar ao mesmo tempo espaços e linguagens.

E assim Certeau foi se inscrevendo na geografia da pesquisa social a ele contemporânea, e ao mesmo tempo nela/dela se diferenciando. No diálogo com Bourdieu, ele assinalou a necessidade de pensar o papel atribuído às práticas na construção de uma teoria científica, questionando o motivo pelo qual toda possibilidade de ação tem que ser sempre analisada por uma racionalidade dominante. Encerrar as práticas sociais na forma do habitus e, desse modo, sob a lei da reprodução, seria uma produção resultante dessa operação. Assim, para Certeau, Bourdieu, com a teoria que formulou sobre as práticas sociais, pareceu sair em direção às táticas, mas entrou de novo (na ordem institucional) para confirmar a racionalidade profissional.

Antes de passar para o último tópico deste capítulo, que versará sobre a relação entre a universidade e a cultura de massa, consideramos importante destacar parte da narrativa Luce Giard que abre o volume dois de A invenção do cotidiano (1996). Ela nos conta um pouco sobre o modo como Certeau conduziu o trabalho no seu grupo de pesquisa, sem impor seus postulados e seus métodos, configurando, com essa atitude, um gesto de rebeldia e delicadeza. 
Na pesquisa ele praticava, com uma flexibilidade inteligente e com a mesma delicadeza que usava no contato pessoal com os outros, coisas de que fizera sua teoria. Assim, toda operação de pesquisa era concebida como a realização de um teste aplicado a hipóteses claramente enunciadas, com as quais se devia lealmente tratar materiais, a fim de 'trazer à tona as diferenças'. Se ele colocava tão alto a operatividade da análise a produzir, é porque não se satisfazia com a partilha estabelecida entre as disciplinas do saber. Recusava-se a acreditar que a 'centificidade' fosse sempre o apanágio de certos campos do saber (Giard, 1996, p. 18).

Ainda conforme o relato de Giard, Certeau dava muita importância à produção de dados e incentivava o desejo de uma virada do olhar analítico. "Era preciso captar ao vivo a multiplicidade das práticas, não sonhá-las, conseguir fazer que se tornassem inteligíveis, para que outros, por seu turno, pudessem estudar as suas operações" (Giard, 1996, p. 21).

\section{A universidade e o ensino em um contexto de constantes mudanças culturais}

A reflexão sobre a universidade e o ensino superior foi realizada por Michel de Certeau em meio ao clamor dos acontecimentos de Maio de 1968 e publicada no livro A cultura no plural, cuja primeira edição data de 1974, portanto, antes da formulação de sua epistemologia das práticas cotidianas. Ainda assim, consideramos que algumas problematizações esboçadas nessa reflexão podem nos ajudar a pensar o que se passa na nossa contemporaneidade, bem como nos ajudar a produzir "a virada do olhar" necessária à produção de novas questões.

Para Certeau (1995, p. 101), a universidade tinha que solucionar, naquele momento e lugar, um problema para o qual 
a tradição não a havia preparado: "a relação entre a cultura de massa e seu recrutamento". Trata-se, em outros termos e trazendo a questão para os dias atuais e para a realidade brasileira, de pensar a democratização do acesso e os modos como as universidades reagem à presença dessas populações antes excluídas. Nesse contexto, nos deparamos com um pensamento não muito otimista em relação ao que foi possível constatar. Nas palavras do autor (pp. 101-2):

Sob esse duplo choque, a universidade fragmenta-se em tendências contrárias. Umas os muros pela seleção da admissão e radicalizando interiormente as 'exigências' de cada disciplina por um controle mais rigoroso. Essa política de 'não nos renderemos' visa a defender a honra e os direitos da ciência estabelecida. Outros deixam a massa dos estudantes calcar sob os pés as guardas dos canteiros da tradição: eles se apoiam na 'mistura' e na discussão para elaborar uma linguagem cultural nova, Há muito tempo essa política de diálogo, pelas incertezas e balbucios em que ela muitas vezes resulta, foi reduzida a ilhas acusadas de negligência, de ideologização, de incompetência.

São duas formas extremas e radicais de reação, nas quais quem paga a conta são os estudantes. No entanto, o que interessava a Certeau era um problema urgente e novo colocado pela entrada maciça das classes médias nas instituições de ensino superior: a relação da cultura com a sociedade e com a universidade. Desde então, segundo o autor, tornou-se necessário compreender que "a cultura não está mais reservada a um grupo social; ela não mais constitui uma propriedade particular de certas especialidades profissionais (docentes, profissionais liberais); ela não é mais estável e definida por um código aceito por todos" (Certeau, 1995, pp. 103-4). 
Parece óbvio, mas até hoje esse não é um ponto de vista compartilhado por muitos praticantes das comunidades acadêmicas. Contudo, como advertiu o próprio Certeau, o docente que ignora a heterogeneidade de referências, inclusive linguísticas, e a cultura caleidoscópica de seus estudantes mantendo um discurso próprio, acreditando falar em nome de um saber superior (por suas referências e suas origens), corre o risco de não se fazer ouvir.

Nessas circunstâncias, conforme a análise, quanto menos operacional a universidade se apresenta em relação à expectativa sociocultural, mais discriminatória ela se torna. Para evitar este risco, seria útil começar por compreender a forma que toma a produção e a expressão de sentidos na cultura contemporânea. Os procedimentos adotados pelos jovens daquela época descritos por Certeau nos dão pistas sobre esses modos de fazer e de dizer. Para o autor (1995, p. 114):

Com efeito, muitas vezes, com os materiais de sua cultura, o estudante procede por colagens, como aliás se faz uma 'bricolagem' individual de vários registros sonoros ou uma combinação de pinturas 'nobres' com imagens publicitárias. A criatividade é o ato de reempregar e associar materiais heterogêneos. O sentido prende-se à significação que esse emprego lhes confere. Esse sentido nada diz por si mesmo; ele elimina todo valor sagradode que seria dotado um signo particular; implica rejeição de todo objeto tido como 'nobre' e permanente.

Considerando os desafios que uma compreensão complexa da cultura apresenta, Certeau defendeu que o ensino não tenha por princípio um conteúdo comum e sim um estilo, tornando-se, dessa forma, compatível com a heterogeneidade dos conhecimentos e das experiências dos estudantes e professores. 
A universidade, nessa perspectiva, deve semear o "ato criador" e tornar-se um laboratório de produção cultural, adequando os seus métodos às questões e às necessidades socioculturais, além de falar uma linguagem que não seja estranha à maioria de seus praticantes.

A título de sistematização, enfatizamos que o reconhecimento da heterogeneidade dos conhecimentos e das experiências de professores e estudantes e a constatação da impossibilidade da educação ter, por princípio e por base, um conteúdo comum a todos, conferem, por si só, relevância e atualidade a essa reflexão. 


\section{CAPÍTULO 3}

\section{A potência das práticas e as artes de fazer com}

"Sempre é bom recordar que não se deve tomar os outros por idiotas" (Certeau apud Giard, 1994, p. 19). É preciso “tomar em conta a experiência do outro" (Certeau, 2006, p.10). As práticas sociais remetem a "mil maneiras de jogar/desfazer o jogo do Outro” (Vidal, 2005, p. 275). Para Michel de Certeau, as práticas cotidianas não são meramente pano de fundo, mas estão no cerne da constituição do social.

Não só a análise, mas os seus modos operacionais dependem do Outro ao qual confrontam e dos usos que fazem do $\mathrm{Ou}-$ tro e com os Outros. De acordo com Josgrilberg (2005, p. 101), na análise certeauniana, "as práticas cotidianas também dependem do que recebem - o Outro que as precede”. Trata-se, então, de uma atividade produtiva que sempre depende de e está em constante tensão com um Outro. Tal abordagem constitui um modo de análise da atividade social que possibilita o questionamento do postulado histórico do atomismo social. Nas palavras de Certeau (1994, p. 38):

De um lado, a análise mostra antes que a relação (sempre social) determina seus termos, e não o inverso, e que cada individualidade é o lugar onde atua uma pluralidade incoerente (e muitas vezes contraditória) de suas determinações relacionais. De outro lado, e sobretudo, a questão tratada se refere a modos de operação ou esquemas de ação e não diretamente ao sujeito que é o seu autor ou seu veículo. Ela visa uma lógica operatória cujos modelos remontam talvez às astúcias multimilenares 
dos peixes disfarçados ou dos insetos camuflados, e que, em todo o caso, é ocultada por uma racionalidade hoje dominante no Ocidente. Este trabalho tem, portanto, por objetivo, explicitar as combinatórias de operações que compõem também (sem ser exclusivamente) uma 'cultura' e exumar os modelos de ação característicos dos usuários, dos quais se esconde, sob o pudico nome de consumidores, o estatuto de dominados (o que não quer dizer passivos ou dóceis). O cotidiano se inventa com mil maneiras de caça não autorizada.

O estudo das práticas ou das "artes de fazer" cotidianas implica, para Certeau, interrogar as operações dos usuários dos produtos culturais, buscando compreender o que fabricam com os usos que fazem do que recebem ou do que lhes é imposto. A essa fabricação ele chama de poética, ou seja, uma produção astuciosa, dispersa, silenciosa e quase invisível, "que não se faz notar com produtos próprios, mas nas maneiras de empregar os produtos impostos por uma ordem econômica dominante" (Certeau, 1994, p. 39).

A presença ou a circulação de artefatos culturais, inclusive dos discursos, normas ou representações ensinadas por "pregadores, educadores ou por vulgarizadores" (Certeau, 1994, p. 40), não garante o que eles são para seus usuários. Assim, somente ao analisarmos os usos que são feitos desses artefatos é que podemos apreciar a diferença entre a produção imposta e a produção secundária que se realiza nos processos de sua utilização.

A ênfase dada está, portanto, preferencialmente, na performatividade das práticas e na diferença que elas instituem em relação aos sistemas de referência que recebem, e não, exclusivamente, na performatividade do discurso, do objeto, da imagem, da lei, norma ou da representação e na repetição que tais artefatos sugerem. Para Certeau (1994, p. 41): 
Essas 'maneiras de fazer' constituem as mil práticas pelas quais usuários se reapropriam do espaço organizado pelas técnicas de produção sócio-cultural [sic]. Elas colocam questões análogas e contrárias às abordadas no livro de Foucault: análogas, porque se trata de distinguir as operações quase microbianas que proliferam no seio das estruturas tecnocráticas e que alteram o seu funcionamento por uma multiplicidade de 'táticas' articuladas sobre os 'detalhes' do cotidiano; contrárias por não se tratar de precisar como a violência da ordem se transforma em tecnologia disciplinar, mas de exumar as formas sub-reptícias que são assumidas pela criatividade dispersa, tática e bricoladora dos grupos ou dos indivíduos presos agora nas redes de 'vigilância'.

\section{Táticas e estratégias}

Ao pensar os modos de proceder da criatividade cotidiana, Certeau formula sua teoria sobre a formalidade das práticas visando a análise de suas lógicas operacionais. Tomando de empréstimo o modelo da guerra, ou melhor,da guerrilha, emprega os conceitos de tática e estratégia para explicar tais procedimentos. Como defende Certeau (1994, pp. 46-7):

Chamo de 'estratégia' o cálculo de relações de forças que se torna possível a partir do momento em que um sujeito de querer e poder é isolável em um 'ambiente'. Ele postula um lugar capaz de ser circunscrito como um próprio e, portanto, capaz de servir de base a uma gestão de suas relações com uma exterioridade distinta. A racionalidade política, econômica ou científica foi construída segundo esse modelo estratégico. Denomino, ao contrário, 'tática' um cálculo que não pode contar com um próprio, nem portanto com uma fronteira que distingue o outro como totalidade visível. A tática só tem por lugar o do outro. Ela aí se insinua, fragmentaria- 
mente, sem apreendê-lo por inteiro, sem poder retê-lo à distância. Ela não dispõe de base onde capitalizar seus proveitos, preparar suas expansões e assegurar uma independência em face das circunstâncias. O 'próprio' é uma vitória do lugar sobre o tempo. Ao contrário, pelo fato de seu não lugar, a tática depende do tempo, vigiando para 'captar no voo' possibilidades de ganho. Tem sempre que jogar com os acontecimentos para os transformar em 'ocasiões'.

Para Certeau, muitas práticas cotidianas são táticas. São maneiras de fazer que produzem vitórias do fraco sobre o forte, constituindo pequenos sucessos, artes de dar golpes, astúcias de caçadores, achados que provocam euforias, tanto poéticos quanto bélicos. São modalidades de ação que utilizam referências de um "lugar" próprio, ou seja, "um espaço que é controlado por um conjunto de operações, 'estratégias', fundadas sobre um desejo e sobre um conjunto desnivelado de relações de poder" (Josgrilberg, 2005, p. 23). As operações táticas desorganizam e reorganizam os lugares, transformando-os em espaços praticados. Assim, a ordem e as normas criadas nesses lugares próprios e impostas aos praticantes da cultura são, subvertidas pelos desvios produzidos pelas práticas.

Essa lógica operatória, como a ideia da métis grega que inspirou Certeau, "não se manifesta abertamente pelo que ela é", não se mostra ao pensamento com clareza, "ela aparece sempre mais ou menos 'nos vãos', imersa numa prática que não se preocupa [...] em explicar sua natureza, nem em justificar seu procedimento" (Detienne e Vernant, 2008, p.11). Ainda segundo esses dois autores, a métis sugere uma manobra que vai permitir ao mais fraco mudar uma situação desfavorável e triunfar sobre o mais forte. 
O homem que possui a métis está sempre prestes a saltar; ele age no tempo de um relâmpago. Isto não quer dizer que ele cede, como fazem comumente os heróis homéricos, a um impulso súbito. Ao contrário, sua métis soube pacientemente esperar que se produzisse a ocasião esperada. Mesmo quando ela procede de um impulso brusco, a obra da métis situa-se nos antípodas da impulsividade. A métis é rápida, pronta como a ocasião que deve apreender o voo, sem deixá-la passar (Detienne e Vernant, 2008, pp. 21-2).

Apesar da dicotomia aparente, Josgrilberg (2005) adverte que em Certeau não há divisões engessadas e que táticas e estratégias, fraco e forte, espaço e lugar só podem ser pensados juntos, como posições instáveis e temporárias que se coengendram. Conforme esse crítico da obra certeauniana, o lugar é ponto de partida, o começo de uma caminhada. Lugar e itinerário estão intimamente ligados, embora não possam ser reduzidos um ao outro. Ir além do lugar é abrir-se à diferença, para a não identidade.

A tática, nessa perspectiva, é uma modalidade de ação, que "exerce-se sobre um terreno móvel, em uma situação incerta e ambígua" (Detienne e Vernant, 2008, p. 21), na qual forças antagônicas se enfrentam. Reinveste inteligências imemoriais, podendo instituir, como resultado da ação, espaços de contestação, resistência e diferença mesmo onde se supõe apenas domínio e alienação.

Em sua análise das práticas, Michel de Certeau deu uma atenção especial aos gestos, mais precisamente à moral dos gestos, o que segundo Schmitt (2005) pode ser atribuído à relevância destes nos rituais religiosos, cuja reflexão a respeito teria sido realizada, em grande parte, por pensadores cristãos.

Conforme esse autor, os gestos são comportamentos individuais que remetem a aquisições sociais, fruto de aprendizagens 
e mimetismos, inconscientes ou não. A análise dos gestos requer atenção aos movimentos do corpo, aos modos de caminhar, às maneiras de sentar, enfim, às atitudes e aos movimentos do corpo. Para Certeau (1996), tal análise é producente para a apreensão dos modos de praticar, reorganizar e ressignificar os lugares.

Vidal (2005) sugere que a análise das artes de fazer, enquanto operações de uso, pode ser feita a partir de duas formas de abordagem. A primeira leva em conta a relação que as práticas estabelecem com um sistema ou com uma ordem. A segunda se ocupa das relações de força que definem as redes em que elas se inscrevem.

\section{A questão da prática em Certeau}

Um dos aspectos centrais do trabalho de Certeau refere-se ao modo original como ele percebe que se deve estudar e pesquisar as práticas, vendo-as como criação dos praticantespensantes no "uso" que fazem de todos os artefatos culturais colocados à disposição para consumo - de artefatos materiais a produtos políticos. As suas ações (táticas) nos processos de viver permitem a tessitura de inúmeras redes nas quais se produzem, sem cessar conhecimentossignificações.

Certeau (1994, p. 110) sabendo que “'os objetos' de nossas pesquisas não podem ser destacados do 'comércio' intelectual e social que organiza as suas distinções e seus deslocamentos", precisa desenvolver diálogos - com o necessário esclarecimento das aproximações e distanciamentos que tem, na proposta que desenvolve - com relação ao pensamento de inúmeros pensadores, dos quais se destacam Bourdieu e Foucault, ${ }^{1}$ por um lado, e Detienne e Vernant, de outro. Acerca do trabalho

1 Bem como Diderot, Durkheim e Freud, além alguns outros que aparecem para indicar a historicidade das posições de Bourdieu e Foucault, os dois pesquisadores maiores que marcavam o período de produção de Certeau. 
dos dois primeiros, com toda a admiração que tem por esses pensadores, Certeau (1994, p. 132) observa que:

esses dois monumentos situavam um campo de pesquisa quase em dois polos opostos. No entanto, por mais afastadas que se encontrem, as duas obras parecem ter em comum o processo de sua fabricação. Nelas se pode observar um mesmo esquema operacional, apesar da diferença dos materiais utilizados, das problemáticas em jogo e das perspectivas abertas. Aqui se teria duas variantes de uma 'maneira de fazer' a teoria das práticas. [...] essa operação teorizante se resume em dois momentos: em primeiro lugar, destacar e, depois, por do avesso. Em primeiro lugar, um isolamento 'etnológico'; depois, uma inversão lógica.

O autor (p. 133) passa, então, a analisar esses dois momentos, indicando inicialmente que

o primeiro gesto destaca certas práticas num tecido indefinido, de maneira a tratá-las como uma população à parte, formando um todo coerente mas estranho no lugar de onde se produz a teoria. Assim os procedimentos 'panópticos' de Foucault, isolados em uma multidão, ou as 'estratégias' de Bourdieu, localizadas entre bearneses ou os kabilinos. Deste modo, recebem uma forma etnológica. Além do mais, tanto num como no outro, o gênero (Foucault) ou o lugar (Bourdieu) que foi isolado é considerado como metonímia do espaço integral: uma parte (observável por ter sido circunscrita) é considerada como representativa da totalidade (indefinível) das práticas.

Certeau (pp. 133-4) mostra, então, o comum, também no segundo movimento do processo de pensar nos dois cientistas dizendo que 
o segundo gesto inverte ou põe do avesso a unidade assim obtida por isolamento. De obscura, tácita e distante, ela se muda no elemento que esclarece a teoria e sustenta o discurso. Em Foucault, os procedimentos escondidos nos detalhes da vigilância escolar, militar ou hospitalar, microdispositivos sem legitimidade discursiva, técnicas estranhas às Luzes, tornam-se a razão por onde se esclarecem ao mesmo tempo o sistema de nossa sociedade e o das ciências humanas. Por elas e nelas, nada escapa a Foucault. Permitem a seu discurso ser ele mesmo e teoricamente panóptico, ver tudo. Em Bourdieu, o lugar distante e opaco organizado por 'estratégias' cheias de astúcias, polimórficas e transgressoras quanto à ordem do discurso é igualmente invertido para fornecer sua evidência e sua articulação essencial à teoria que reconhece em toda a parte a reprodução da mesma ordem. Reduzidas ao habitus que ali se exterioriza, essas estratégias inconscientes de seu saber proporcionam a Bourdieu o meio de explicar tudo e tomar consciência de tudo. [grifos pelo autor]

Para deixar claro que isto não ocorre só com esses dois cientistas, pois é questão de estarem na mesma órbita de necessidades que outros e portando as mesmas "marcas" científicas, Certeau (1994, pp. 134-5) busca ainda dois outros "monumentos" do início do século XX: Durkheim, em As formas elementares da vida religiosa, e Freud, em Totem e Tabu. Da mesma maneira, esses dois cientistas

quando constroem uma teoria das práticas, eles as situam primeiro num espaço 'primitivo' e fechado, etnológico em cotejo com nossas sociedades 'esclarecidas', e reconhecem ali, neste lugar obscuro, a fórmula teórica de sua análise. É nas práticas sacrificais dos Arunta, da Austrália, etnia certamente primitiva entre as 'primitivas', que Durkheim descobre o princípio de uma 
ética e de uma teoria sociais contemporâneas: a restrição contraposta (pelo sacrifício) ao querer indefinido de cada indivíduo possibilita de um lado uma coexistência e, de outro, convenções entre membros de um grupo. Noutras palavras, a prática da renúncia e da abnegação permite uma pluralidade e contratos, isto é, uma sociedade: o limite aceito funda o contrato social.

Quanto a Freud, nas práticas da horda primitiva, ele decifra os conceitos essenciais da Psicanálise: o incesto, a castração, a articulação da lei a partir da morte do pai. Inversão tanto mais impressionante, por não ter nenhuma experiência direta a justificá-la. Nem um, nem outro observou as práticas que aborda. Não foram nunca observá-las diretamente, da mesma forma que Marx nunca foi a uma fábrica. Por que, portanto, a constituição dessas práticas em enigma fechado onde se vai ler pelo avesso a palavra-chave da teoria?

Para Certeau, essa questão central vai ter sua resposta na História. Essa inversão/esse corte se dá porque é imposto pela história da busca científica na Modernidade: é assim que o Leviatã foi "imaginado" e que se acreditou trazer para o "laboratório" a Natureza. Sobre todos esses autores, podemos dizer, assim, além de concordar com Certeau quando os reconhece "monumentos", já que deixaram em nós as "marcas" de suas teorias, que eram, todos, "homens de seu tempo".

Certeau vai dar sua contribuição buscando mostrar que talvez não se deva mais "ler" nos autores que nos precederam a distinção entre "teoria" e "prática", mas sim as operações que diferenciam as formas como estudam "a prática", quando a essas atribuem um discurso. Certeau afirma que as práticas são não discursivas e entende que devem ser estudadas exatamente pela sua "não discursividade". 
Mostra, então, como foi este processo de separar o discursivo do não discursivo, historicamente, ao indicar o que foi feito na Enciclopédia (por Diderot e D’Alembert) e 150 anos mais tarde (por Durkheim), dizendo que

ela [a Enciclopédia] coloca lado a lado, numa proximidade que é promessa de assimilação ulterior, as 'ciências' e as 'artes'; umas são línguas operatórias cuja gramática e sintaxe formam sistemas construídos e controláveis, portanto, escrevíveis; as outras são técnicas à espera de um saber esclarecido e que lhes falta. No artigo 'Arte,' Diderot tenta precisar a relação entre esses elementos heterogêneos. Estamos diante de 'arte', escreve ele, 'se o objeto é executado'; diante de uma 'ciência', 'se o objeto é contemplado'. Distinção mais baconiana do que cartesiana, entre execução e especulação. [...] A arte é, portanto, um saber que opera fora do discurso esclarecido e que lhe falta. Mais ainda, esse saber-fazer precede, por sua complexidade, a ciência esclarecida. [...] Estranhas para as 'línguas' científicas, elas constituem fora delas um absoluto do fazer (uma eficácia que, livre do discurso, testemunha, no entanto, seu ideal produtivista) e uma reserva de saberes que se deve inventariar nas 'oficinas' ou nos campos (há um Logos escondido no artesanato e ele já murmura o futuro da ciência). Uma problemática de retardamento se introduz na relação entre ciência e artes. Um handicap temporal separa dos saber-fazer a sua progressiva elucidação por ciências epistemologicamente superiores (Certeau, 1994, p. 137).

O autor (pp. 137-9) termina sua exposição acerca do pensamento da Enciclopédia, dizendo: "estranha disparidade entre o tratamento dado às práticas e o dado aos discursos. Onde o

2 Todas as palavras com aspas simples são destaques de Certeau (1994) em seu texto. 
primeiro registra uma 'verdade' do fazer, o outro decodifica as 'mentiras do dizer". Mostra, a seguir, que 150 anos depois Durkheim adota esta mesma posição "etnológica", e mesmo reforçando-a já que aborda "o problema da arte (de fazer), isto é, 'aquilo que é prática pura sem teoria”. Certeau (p. 139) vai dizer então como as práticas vão ser analisadas por Durkheim:

enquistada na particularidade, desprovida das generalizações que fazem a competência exclusiva do discurso, a arte nem por isso deixa de formar um 'sistema' e organizar-se por 'fins' - dois postulados que permitem a uma ciência e a uma ética conservar em seu lugar o discurso 'próprio' de que está privada, isto é, escrever-se no lugar e em nome dessas práticas.

Neste ponto de sua análise do pensamento de Durkheim, Certeau vai lembrar sua grande relação com a educação. Diz, então, Certeau (p. 140):

característico, também, o interesse pela produção ou pela aquisição da arte por este grande pioneiro que ligou a fundação da sociologia a uma teoria da educação: 'Não se pode adquiri-la a não ser pondo-se em relação com as coisas sobre as quais se deve exercer a ação e exercendo-a pessoalmente'. À 'imediaticidade' da operação, Durkheim não opõe mais, como o fazia Diderot, um atraso da teoria quanto ao saber manual das oficinas. Permanece apenas trançada a uma hierarquia estabelecida sobre o critério da educação: 'sem dúvida - prossegue Durkheim - pode acontecer que a arte seja esclarecida [eis a palavra-chave das Luzes] pela reflexão, mas a reflexão não é o seu elemento essencial, 
pois a arte pode existir sem ela. Mas não existe uma só arte em que tudo seja fruto da reflexão.3

A partir desta análise, Certeau (p. 140) nos vai colocar aquela que é uma pergunta-chave de seu trabalho: "existiria, então, uma ciência onde 'tudo seja fruto da reflexão'?"

Esta é a questão que Certeau vai responder ao fazer sua proposta teórico-metodológica, que também é teórico-epistemológica, da "invenção do cotidiano - as artes de fazer".

A partir deste movimento - do modo como a ciência percebe a prática como o Outro da teoria -, segundo Certeau (1994), se dá o surgimento do "terceiro homem" que reuniria em si a ciência e a arte. Ele seria o engenheiro, em seus momentos iniciais, e, hoje, o tecnocrata que domina dados e se utiliza de máquinas, demonstrando a superioridade destas para substituir as atividades manuais, dos primeiros "arteiros", cujos saberes foram transformados em máquinas.

Só restaria então, na análise de Certeau (1994), como saberes - originados nas/das/com as práticas - aqueles que não têm legitimidade aos olhos da racionalidade produtivista - as artes do dia a dia na cozinha, artes de limpeza, da costura etc. Como o são também as repetições necessárias realizadas pela professora para ensinar as primeiras letras, os primeiros números, as primeiras relações com a natureza... ou ainda, aos estudantes mais velhos, os períodos históricos, as massas atmosféricas etc.

Para chegar a sua proposta, Certeau (1994) percorre o que ele chama o tempo das histórias - em oposição ao tempo da História - , fazendo uma apresentação do modo como Detienne ${ }^{4}$

3 DURKHEIM, Emile. Education et sociologie. Paris: Alcan, 1922, p. 87. Ver BORDIEU, Pierre. Esquisse d'une théorie de la pratique. Genebra: Droz, 1972, p. 211, que reconhece aí uma "perfeita descrição" da "douta ignorância" (Nota 12 de Certeau, 1994, p. 333).

4 Marcel Detienne é um historiador francês que se formou na equipe de Vernant, trabalhando com História grega. 
trabalha em suas obras, reconhecendo que este faz uso de narrativas e com elas trabalhando como uma arte de dizer e através de uma tática que é a de contar os lances. Sobre isto escreve Certeau (1994, pp. 155-6):

ele [Detienne] não instala as histórias gregas diante de si para tratá-las em nome de outra coisa que não elas mesmas. Recusa o corte que delas faria objetos de saber, mas também objetos a saber, cavernas onde 'mistérios' postos de reserva aguardariam da pesquisa científica o seu significado. Ele não supõe, por trás de todas essas histórias, segredos cujo progressivo desvelamento lhe daria, em contrapartida, o seu próprio lugar, o da interpretação. Esses contos, histórias, poemas e tratados para ele já são práticas. Dizem exatamente o que fazem. São o gesto que significam. Não há necessidade alguma de lhes acrescentar alguma glosa que saiba o que exprimem sem saber, não perguntar de 'que' são a metáfora. Formam uma rede de operações da qual mil personagens esboçam as formalidades e os bons lances. Neste espaço de práticas textuais, como num jogo de xadrez cujas figuras, regras e partidas teriam sido multiplicadas na escola de uma literatura, Detienne conhece como artista mil lances já executados (a memória dos lances antigos é essencial a toda partida de xadrez), mas ele joga com esses lances; dele faz outros com esse repertório: 'conta histórias' por sua vez. Re-cita esses gestos táticos. Para dizer o que dizem, não há outro discurso senão eles. Alguém pergunta: mas o que 'querem' dizer? Então se responde: vou contá-los de novo. [...] O mesmo acontece com a recitação da tradição oral, assim como a analisa J. Goody: ${ }^{5}$ uma maneira de repetir séries e combinações de operações formais, com uma arte de 'fazê-las con-

5 GOODY, Jack. "Mémoires et apprentissage dans les sociétés avec ou sans écriture: la transmission du Bagre”. In L'Homme, t. 17, 1977, pp. 29-52. E, do mesmo autor, The domestication of the savage mind. Cambridge: Cambridge Univerty Press, 1977 (N. de Certeau, 1994, p. 335). 
cordar' com as circunstâncias e com o público. O relato não exprime uma prática. Não se contenta em dizer um movimento. Ele o 'faz'.

Certeau estuda as diversas obras desse autor, mas se detém, particularmente, na que Detienne escreveu com Vernant sobre a "métis" grega e que recebeu o título As astúcias da inteligência. ${ }^{6}$ Com relação à análise que faz desse livro, Certeau (1994, p. 157) diz:

três elementos me prendem mais a atenção, por diferenciarem mais nitidamente a 'métis' em face de outros comportamentos, mas também por caracterizarem igualmente os relatos que falam dela. É a tríplice relação que a 'métis' mantém com 'a ocasião', com os disfarces e com uma paradoxal invisibilidade. De um lado, a 'métis' conta com o 'momento oportuno' (o Kairós) e o aproveita: é uma prática do tempo. De outro lado, multiplica as máscaras e as metáforas: é uma defecção do lugar próprio. Enfim, desaparece no seu próprio ato, como que perdida no que faz, sem espelho para representá-la; não tem imagem própria. Esses traços da 'métis' podem igualmente atribuir-se ao relato. Sugerem, então, um 'suplemento' a Detienne e Vernant: a forma de inteligência prática que analisam e a maneira como o fazem devem ter entre si um nexo teórico se a narratividade contadora é também algo semelhante a uma 'métis'.

O grande espaçotempo que possibilita a realização da métis é, assim, a memória de lances vividos: "um saber que se faz de muitos momentos e de muitas coisas heterogêneas. Não tem enunciado geral e abstrato, nem lugar próprio" (Certeau, 1994, p.

6 DETIENNE, Marcel e VERNANT, Jean-Pierre. Les ruses de l' intelligence: la métis des Grecs. Paris : Flammarion, 1974 (N. de Certeau, 1994, p. 335). 
157). O autor (pp. 162-3) vai entender que esta memória é móvel, afirmando que

sua mobilização é indissociável de uma 'alteração'. Mais ainda, a sua força de intervenção, a memória obtém de sua própria capacidade de ser alterada - deslocável, móvel, sem lugar fixo. [...] Longe de ser relicário ou lata de lixo do passado, a memória vive de 'crer nos possíveis, de esperá-los, vigilante, à espreita. [...] A arte da memória desenvolve a aptidão para estar sempre no lugar do outro mas sem apossar-se dele, e a tirar partido dessa alteração mas sem se perder aí. Essa força não é um poder (mesmo que seu relato o possa ser). Recebeu antes o nome de autoridade: aquilo que 'tirado' da memória coletiva ou individual, 'autoriza' (torna possíveis) uma inversão, uma mudança de ordem e de lugar, uma passagem a algo diferente, uma 'metáfora' da prática ou do discurso. 


\section{CAPÍTULO 4}

\section{Cotidiano, cultura, alteridade e a criação permanente de diferença}

No ocidente, o grupo (ou indivíduo) se robustece com aquilo que exclui (é a criação de um lugar próprio) e encontra sua segurança na confissão que extrai de um dominado (assim se constitui o saber de/sobre o outro, ou ciência humana) (Certeau, 2006, p. 17).

Toda ciência humana deve introduzir a suspeita em seu próprio desenvolvimento para interrogar sobre sua relação histórica com um tipo social. Ela está vinculada a uma forma de cultura. Para se definir novamente, deve fazer uma análise contestadora da civilização que ela postula (Certeau, 1995, p. 173).

Michel de Certeau foi um homem antenado com os movimentos sociais, políticos, artísticos e intelectuais do seu tempo, mais precisamente com aqueles que se engendraram entre os anos 1960 e 1990, e agitaram tanto Paris quanto a Califórnia, além do Rio de Janeiro, de Salvador e de tantos outros lugares nos quais viveu e/ou visitou, e onde experimentou e destacou singularidades, mestiçagens, engenhosidades, inventividades, conveniências e pequenas liberdades forjadas com as práticas cotidianas na contingência das chamadas "cultura de massa" e/ou "sociedade de consumo", as quais se tornaram os principais objetos elaborados por inúmeros estudos, apocalípticos ou integrados, das ciências sociais e humanas à época.

Em meio a esses movimentos, em que modelos explicativos como o marxismo, o estruturalismo e o funcionalismo co- 
meçaram a serem postos em xeque, Certeau, de alguma forma, foi afetado pela "virada culturalista", pela "virada linguística", pela psicanálise, por alguns pressupostos do pós-estruturalismo, pela Escola dos Annales, assim como por outras críticas a esses modelos teleológicos e comprometidos com o Iluminismo.

Da mesma forma, deixou-se atravessar pelos movimentos das ruas, como o Maio de 1968 na França, as guerrilhas na América do Sul, África e Ásia, as guerras pela independência nas ex-colônias, as migrações pós-coloniais, as reivindicações de minorias raciais, étnicas, de gênero, de geração, de região geopolítica, entre outras, bem como pelo desenvolvimento da "indústria cultural" e das mídias, em especial, pela televisão. Todas essas afetações não o levaram a filiar-se a nenhuma tendência ou escola de pensamento, mas ajudaram-no a criar uma "ciência prática do singular".

Sensível a esses movimentos, o intelectual conhecido por estudar a mística religiosa na Idade Média, dedicou-se também à investigação das transformações culturais que vinham ocorrendo em vários pontos do planeta na segunda metade do século XX, deslocando para a investigação do presente algumas noções que lhe eram úteis em seus trabalhos no campo da teologia, tais como a ideia de métis, a inteligência prática e astuciosa dos heróis e deuses analisada por Detienne e Vernant (2008) a partir de um estudo da mitologia, e a importância dos gestos, mais precisamente da moral dos gestos, a partir da relevância destes nos rituais religiosos, cuja reflexão a respeito teria sido realizada, de acordo com Schmitt (2005), em grande parte, por pensadores cristãos. Essas noções foram apropriadas em suas análises da cultura como criação anônima que se forja por palavras e gestos que se coengendram com as práticas cotidianas 
(verbais e não verbais) dos homens e mulheres ordinários, produzindo sempre diferença, heterogênese, multiplicidades.

Certeau, portanto, não se deteve, demorada e diretamente, sobre a questão da identidade e da diferença cultural (ambas, o modelo e seu negativo, entendidas como formas originárias, fixas, puras, opostas e excludentes), tal qual ela seria, algumas vezes, exposta por outras abordagens dentro dos Estudos Culturais, inclusive nas pesquisas em educação. Embora tenha legitimado e defendido a mobilização e a organização das minorias em torno de reivindicações para que as políticas públicas lhes garantissem seus direitos, ele preocupou-se, principalmente, com a produção de "lugares próprios" no contexto das relações de forças, do exercício do poder.

Tratava-se de desnaturalizar as operações que levam os discursos produzidos em tais lugares a falarem em nome do real e da verdade sobre o Outro, silenciando-o e fabricando os modos como ele deve ser percebido, subjetivado, objetivado, assistido, dominado, controlado e governado. Certeau (1995, p. 232) se debruçou, por exemplo, sobre o lugar próprio instituído pela ciência de uma forma geral e pela história em particular para desocultar os modos pelos quais procedimentos hegemônicos nessas instituições constituíram/constituem "todo o seu resto", ou seja, a "cultura" e "os outros", propondo outra atitude epistemológica: a relação, a confrontação, a legitimação e a comparação com as alteridades, as quais constituem o modo como "o futuro entra no presente".

Ao mesmo tempo em que se dedicava ao estudo das operações que constituem os "lugares próprios", Michel de Certeau voltava-se para a astúcia desses "Outros" do saber/poder ao produzirem com seus modos de fazersaber, informados por seus 
desejos, interesses e referências, desordens e deslocamentos em tais lugares, instituindo, permanentemente, diferença.

A identidade, nessa perspectiva, é pretensão, modelo vazio. A ordem e as normas impostas pelos saberesfazeres criados nesses "lugares próprios", como, por exemplo, a autoridade cultural, são, todo tempo, subvertidas pelos desvios produzidos com as práticas: "a força anônima de uma dor, de uma cólera ou de uma gargalhada da multidão acaba por cativar, inquietar, às vezes invadir e destruir o edifício do saber” (Certeau, 2011, p. 127). Essa lógica operatória, como a métis, "não se manifesta abertamente pelo que ela é", não se mostra ao pensamento com clareza, "ela aparece sempre mais ou menos 'nos vãos', imersa numa prática que não se preocupa [...] em explicar sua natureza, nem em justificar seu procedimento" (Detienne e Vernant, 2008, p. 11).

Essa modalidade de ação, que "exerce-se sobre um terreno móvel, em uma situação incerta e ambígua" (Detienne e Vernant, 2008, p. 21), na qual duas forças antagônicas se enfrentam, remonta, segundo Certeau, a experiências milenares e pode instituir espaços de liberdade e diferença mesmo onde se supõe apenas o domínio e a assimilação, como no seio da colonização. Para o autor (1994, pp. 39-40),

Há bastante tempo que se tem estudado que equívoco rachava, por dentro, o 'sucesso' dos colonizadores espanhóis entre as etnias indígenas: submetidos e mesmo consentindo na dominação, muitas vezes esses indígenas faziam das ações rituais, representações ou leis que lhes eram impostas outra coisa que não era o que o conquistador julgava obter por elas. Os indígenas as subvertiam, não rejeitando-as diretamente ou modificando-as, mas pela sua maneira de usá-las para fins e em função de referências estranhas ao sistema do qual não podiam fugir. Eles eram outros, mesmo no seio da colonização 
que os 'assimilava' exteriormente; seu modo de usar a ordem dominante exercia o seu poder, que não tinham meios para recusar; a esse poder escapavam sem deixá-lo. A força de sua diferença se mantinha nos procedimentos de 'consumo'. Em grau menor, um equívoco semelhante se insinua em nossas sociedades com o uso que os meios 'populares' fazem das culturas difundidas e impostas pelas 'elites' produtoras de linguagem.

Para Michel de Certeau (1194, p. 40), a presença ou a circulação de uma representação ensinada por "pregadores, educadores ou por vulgarizadores", não garante o que ela é para seus usuários. Somente ao analisarmos os usos que são feitos dessa representação é que podemos apreciar a diferença entre a produção da imagem e a produção secundária que se realiza nos processos de sua utilização. A ênfase dada pelo autor está, portanto, preferencialmente na performatividade das práticas e na diferença que elas criam em relação aos sistemas de referência que lhe são estranhos, e não, exclusivamente, na performatividade do discurso, da imagem, da lei, do endereçamento, da representação e na repetição que tais normativas sugerem.

O próprio trabalho de Certeau situou-se nessa diferença e operou uma inversão de perspectiva na abordagem da cultura, circunscrevendo um domínio de investigação no qual as pesquisas nos/com os cotidianos em educação se inscrevem e o qual buscam desenvolver para dar visibilidade e inteligibilidade às operações de praticantes e ao que com elas se cria. Nessa perspectiva, para nós, assim como para Certeau:

O que importa já não é, nem pode ser mais a 'cultura erudita', tesouro abandonado à vaidade dos seus proprietários. Nem tampouco a chamada 'cultura popular', 
nome outorgado de fora por funcionários que inventariam e embalsamam aquilo que um poder já eliminou, pois para eles e para o poder 'a beleza do morto' é tanto mais emocionante e celebrada quanto melhor encerrada no túmulo. Sendo, é necessário voltar-se para a 'proliferação disseminada' de criações anônimas e 'perceptíveis' que irrompem com vivacidade e não se capitalizam (Giard, 1994, p. 13).

A concepção de cultura como redes de criações anônimas e práticas significantes foram emergindo na obra de Certeau em um pensamento que se forjava em meio a mudanças sociais, políticas e intelectuais e que buscava dar conta de um presente em construção. Na obra também manifestou-se a noção de poder como relação que se exerce em toda parte e como algo que ninguém possui, mas que está sempre sendo disputado, embora implique autoridade e força.

Ainda que tenhamos poucos registros a respeito de possíveis debates acadêmicos travados em presença com outros pensadores a ele contemporâneos, encontramos na obra de Certeau vestígios de encontros, diálogos e atravessamentos com outros intelectuais de seu tempo conhecidos em nosso campo da educação, tais como Edgar Morin, Gilles Deleuze, Marc Augé, Bruno Latour, Pierre Bourdieu, Jacques Derrida e Michel Foucault. Algumas problemáticas comuns e noções compartilhadas nos apontam para frequentações e solidariedades intelectuais entre eles, para além das questões manifestas nas conversas explicitadas que Certeau estabeleceu com alguns desses e com outros pensadores em seus livros, quase sempre para desenvolver pensamentos análogos e ao mesmo tempo contrários aos de seus intercessores. 
Entre esses pensadores, por conta do tema abordado nesse capítulo, buscamos uma aproximação com Michel Foucault, por quem, segundo Giard (2011), Certeau tinha não só amizade como também admiração. Com Foucault, Certeau partilhava a necessidade de criar modos pelos quais fosse possível "pensar diferentemente", e destacava, no amigo, a atitude de estranhamento e atenção vigilante para as "citações do impensado". E, ao falar da empreitada teórica de Foucault, Certeau nos dá pistas sobre o que, em comum, entendiam por maneiras de praticar o poder, entre as quais se situam as atividades intelectuais. Como analisa Certeau (2011, pp. 125-6),

Na perspectiva delineada por Michel Foucault, entendo por práticas de poder 'um modo de ação que não age, direta e imediatamente, sobre os outros, mas sobre a ação própria deles'; tais práticas compõem 'um conjunto de ações sobre ações possíveis' (Foucault, 1984). Trata-se, portanto de operações (procedimentos) e não de concepções (ideias), embora elas possam situar-se nos dois registros que, em proporções, variáveis, qualquer poder implica: por um lado, uma autoridade (relativa ao crer/fazer crer); e por outro uma força (relativa a uma pressão ou repressão física).

Para empreendermos a inversão na perspectiva de abordagem da diferença nos diversos contextos culturais cotidianos compreendendo-a como afirmativa e criadora de outras possibilidades para a existência e para o conhecimento, precisamos pensar o poder como um exercício, uma relação de forças, uma luta travada todo dia por indivíduos e grupos sociais, em todos os espaçostempos em que os seres humanos se encontram e se relacionam. Em meio a esse exercício, para manter ou conquistar 
reconhecimento e os benefícios que dele advêm, os praticantes inventam-se a si mesmo e criam cultura.

\section{As Culturas e suas redes de operações}

A cultura oscila mais essencialmente entre duas formas, das quais uma sempre faz com que se esqueça da outra. De um lado ela é aquilo que 'permanece'; do outro aquilo que se inventa. Há, por um lado, as lentidões, as latências, os atrasos que se acumulam na espessura das mentalidades, certezas e ritualizações sociais, via opaca, inflexível, dissimulada nos gestos cotidianos, ao mesmo tempo os mais atuais e milenares. Por outro lado, as irrupções, os desvios, todas essas margens de uma inventividade de onde as gerações futuras extrairão sucessivamente sua 'cultura erudita'. A cultura é uma noite escura em que dormem as revoluções de há pouco, invisíveis, encerradas nas práticas -, mas pirilampos, e por vezes grandes pássaros noturnos, atravessam-na; aparecimentos e criações que delineiam a chance de um outro dia (Certeau, 1995, p. 239).

Certeau foi impelido a mergulhar nessa "noite oceânica", que o instigava e inquietava, como ele mesmo afirmou, em meio ao calor das manifestações de maio de 1968, quando escreveu artigos sobre os "acontecimentos" para a revista Études (periódico sobre cultura publicado pela Companhia de Jesus) e quando colaborou com diversos pareceres, pesquisas e reflexões acadêmicas sobre esse tema, bem como com estruturas de governo na França voltadas para a criação de políticas sociais e culturais nas contingências das mudanças em andamento (Giard, 1995). Recusando-se a uma concepção de cultura no singular, isto é, da cultura da elite tomada como "a cultura", e convencido de que a 
invenção e a criatividade não são apanágio dos profissionais do assunto, ele formula uma série de artigos destacando as redes informais que produzem e fazem circular cultura. Esses artigos serão posteriormente reunidos no livro A cultura no plural, cuja primeira versão foi publicada em 1974, em Paris.

Seis anos depois, no prefácio da edição de 1980, toma esse livro como esboço de travessias que produziram outras pesquisas ( $A$ invenção do cotidiano) e indica que tais travessias requerem uma passagem do "plural" ao múltiplo. Essas reflexões posteriores nos ajudam a nos apropriarmos de várias formulações criadas naquela ocasião, deslocando-as e as ressignificando no espaçotempo para pensarmos problemáticas postas pela questão da cultura, da diferença e da alteridade na contemporaneidade. Trata-se de pensar a ação cultural no contexto dos combates cotidianos, onde se engendra uma arte social de jogar com as instituições e hierarquias: "a cultura pode ser comparada com essa arte, condicionada pelos lugares, regras e dados; ela é uma proliferação de invenções em espaços circunscritos" (Certeau, 1995, p. 19).

Ao pensar a cultura como uma rede de operações produtoras de saberesfazeres, poderes e sentidos, Certeau desloca a compreensão de ação cultural ou política como algo realizado de forma centralizada e de cima para baixo, ou seja, pelas estruturas que buscam o governo dos outros, para as redes de práticas sociais cotidianas que produzem sentidos para aqueles que as realizam. Cultura é uma prática significativa. "Ela consiste não em receber, mas em exercer a ação pela qual cada um marca aquilo que outros lhe dão para viver e pensar" (Certeau, 1995, p. 143). Assim, para o autor (p. 142), não há na socieda- 
de setor particular (religião, ideologia, ciência, mercado, mídia etc.) capaz de "fornecer a todos os outros aquilo que os proverá de significação".

Nessa perspectiva, como assinalou Giard (1995, p. 10), as culturas não constituem um conjunto de valores a serem preservados e defendidos, ao contrário, constituem-se como um trabalho a ser realizado em toda extensão da vida social, o qual "requer uma atividade, um modo de apropriação, uma adoção e uma transformação pessoais, um intercâmbio instaurado em um grupo social”. A inversão na abordagem em relação a outras práticasteorias difundidas à época consiste na desapropriação da cultura no singular (apagamento da propriedade e do nome próprio) e, simultaneamente, em uma passagem a práticas de significação, isto é, a operações produtoras.

\section{Violências, minorias e revoluçōes do crível}

Os atos de violência são justamente designados como 'manifestações'. Eles pretendem quebrar e desmascarar a economia alienante do meio e o totalitarismo da identidade. Sob esse ponto de vista, o ultraje torna-se 'paixão moral'. Ele se faz gesto, porque as palavras foram confiscadas. O desordeiro que quebra o visor da calculadora IBM ou a porta do automóvel procede - mas exteriormente ao texto - como o escritor que trabalha na desconstrução da linguagem. A fenda que ele assinala na rede objetiva dos significados é o correspondente de um lapso de linguagem. Esse ato intercepta com um protesto um universo saturado. A repetição do anônimo cria o análogo de um 'ruído' em que a palavra tem inicialmente a forma de uma fratura, de um buraco, de uma blasfêmia (Certeau, 1995, p. 94). 
Ao trazer para a análise o caso extremo do ato violento nas manifestações, o qual ele denomina como práticas do blasfemo, Certeau (1995, p. 95) busca, no contexto do estudo sobre os acontecimentos de Maio de 1968, assinalar a irrupção de um grupo em uma sociedade que tolera cada vez menos os nascimentos: "ele autentica o querer-existir de uma minoria que procura se constituir em um universo onde ela é excedente porque ainda não se impôs”. Tal nascimento é, para ele, indissociável de uma violência, que, no entanto, reside em um discurso de protesto. Ela opera como um sinal, indica a necessidade de mudanças, abre possibilidades. Contudo, tal atitude não cria; desfaz, mas não instaura. Cabe, então, a tarefa infindável de construir sociedades sobre razões para viver próprias a todos e cada um.

O nascimento das minorias, conforme o entendimento do autor, é forjado por, ao mesmo tempo em que forja, revoluções no crível, as quais levam ao descrédito das autoridades vivenciado por todos.

Os dogmas, os saberes, os programas e as filosofias perdem sua credibilidade, sombras sem corpos que nem a mão, nem o espírito podem capturar e cuja evanescência irrita ou engana o gesto que ainda os procura; eles nos deixam, muitas vezes persistentemente, apenas a ilusão ou a vontade de 'sustentá-los' (Certeau, 1995, p. 27).

Nessas contingências, as autoridades socioculturais tornam-se absurdas por não corresponderem mais à geografia do sentido e os grupos sociais marginalizados, excluídos e/ou inaugurais recusam a não significação e buscam razões comuns para viver. Trata-se do direito de um grupo social formular seus quadros de referência e seus modelos de comportamento. Surgem, 
então, credibilidades nascentes que informam o que há de móvel e de inventivo na vida social. Emergem sinais, crenças e acordos tácitos que tornam possível a elaboração de um comum.

Tais credibilidades nascentes, contudo, não se dizem diretamente e expressam-se por meio do que negam e do que aceitam, do que se apropriam e do que consideram essencial para viver. As revoluções do crível não são, segundo Certeau, reivindicadoras. São discretas e mais terríveis, pois produzem descolamentos na adesão, reorganizando as autoridades aceitas, privilegiando algumas referências e eliminando outras.

\section{Cotidiano, comportamento e reconhecimento}

A noção de conveniência foi desenvolvida no livro $A$ invenção do cotidiano (v. 2), por Pierre Mayol, um dos pesquisadores do grupo dirigido por Michel de Certeau, com base em premissas por ele sugeridas. Trouxemos essa discussão para este capítulo porque entendemos que ela indica um modo de pensar a organização da vida cotidiana através da articulação entre dois registros: os comportamentos e os benefícios simbólicos que se espera adquirir ou conservar, o que pode nos ajudar a pensar a performatividade das práticas na questão dos processos identitários e de diferenciação. Segundo esse pesquisador, a conveniência:

representa, no nível dos comportamentos, um compromisso pelo qual cada pessoa, renunciando à anarquia das pulsões individuais, contribui com sua cota para a vida coletiva, com o fito de daí retirar benefícios simbólicos necessariamente protelados. Por esse 'preço a pagar' (saber 'comportar-se', ser 'conveniente'), o usuário se torna parceiro de um contrato social que ele se obriga a respeitar para que seja possível a vida cotidiana. [...] A contrapartida desse tipo de imposição é para o usuá- 
rio a certeza de ser reconhecido, 'considerado' por seus pares, e fundar assim em benefício próprio uma relação de forças nas diversas trajetórias que percorre (Mayol, 1996, p. 39).

Pensando por esse prisma, ao invés de passivo e manipulado pelas autoridades culturais, o praticante da cultura age, joga o jogo da conveniência em benefício próprio, conserva-se atrás de uma máscara para sair-se bem em seu papel social e altera com seus movimentos as regras do jogo. Para Mayol (1996, p. 40), a prática cultural implica uma combinação, mais ou menos fluida, mais ou menos coerente, de elementos cotidianos (concretos, ideológicos, simbólicos, tradicionais, institucionais) realizada dia a dia através de comportamentos que "traduzem em visibilidade fragmentos desse dispositivo cultural". Essa operação possibilita ao usuário criar e assumir uma identidade na rede das relações sociais inscritas em um ambiente, mantendo-se "na defesa" no interior de códigos sociais em situações de coexistência indecidível e inevitável, em que "sair à rua significa o risco de ser reconhecido, e portanto apontado com o dedo" (Mayol, 1996, p. 47). A ênfase na palavra comportamento, segundo o autor (p.48), indica que o corpo é suporte primeiro da mensagem social proferida:

O corpo é o suporte de todas as mensagens gestuais que articulam essa conformidade: é um quadro-negro onde se escrevem - e portanto se fazem legíveis - o respeito aos códigos ou ao contrário o desvio com relação ao sistema de comportamentos. 
O corpo e seus acessórios, palavras e gestos, têm uma função fundamental no processo de funcionamento da conveniência, cujo estilo de ação - manter-se atrás da máscara favorece uma inserção indefinida, baseada no consentimento e não na coação, no tecido coletivo.

A noção de conveniência possibilitou a Mayol, por exemplo, pensar práticas do espaço público levando em conta a suposta diferença entre os sexos, e permitindo a ele constatar que a ambígua organização sexuada do espaço é constantemente subvertida pelos passos dos usuários, pelos itinerários que criam e pelas práticas de significação que engendram, criando sentidos imprevistos no texto da conveniência.

Certeau e Giard (1996) ao discorrerem sobre a mítica da cidade, destacam que na perspectiva de uma nova estética urbana duas redes retêm particular atenção: os gestos e os relatos. Segundo eles, as duas cadeias de operações, uma tática e outra linguística, deslocam objetos, normas e regras modificando-lhes o emprego e reorganizando os espaços.

O dispositivo da conveniência pode nos ser útil para pensar a questão da identidade não necessariamente como um modelo imposto de cima pra baixo, mas como o resultado da uma adesão a um acordo, uma máscara que possibilita reconhecimento, um saber jogar o perde-ganha que implica renúncia e conquista dos benefícios almejados.

\section{Pesquisar a diferença nos cotidianos das escolas}

O que Certeau nos propõe é pensar "outramente" a diferença nos diversos contextos cotidianos, entre eles as escolas e as redes educativas que as atravessam. Para isso, precisamos, em nossas pesquisas nos/dos/com os cotidianos, de posturas epistemoló- 
gicas, teóricas e metodológicas que nos possibilitem, além de indicar os mecanismos de homogeneização e as dinâmicas de exclusão, repressão e controle exercidos supostamente apenas por um poder centralizador e determinista (articulado em diversos contextos, como o político, o econômico, o cultural, o científico, o religioso etc.), enxergar os usos que os praticantes dos cotidianos escolares fazem deles e os desvios que esses usos produzem, instituindo, permanentemente, diferença. Nessa perspectiva, torna-se relevante compreender os cotidianos como campos de luta, nos quais o poder, como relação de forças, está sempre sendo contestado e disputado. Precisamos, ainda, indicar a multiplicidade de modos de existência e de conhecimentos que, com essas operações de usuários, se engendram e singularizam criando cultura e produzindo sentidos.

Partindo da noção de complexidade como uma das características das redes de operatórias produtoras do sociocultural e na necessidade de pensar paradoxalmente que essa compreensão exige, a dicotomia identidade/diferença (como negativo da primeira) não nos serve mais para pensar a diferença afirmativa e a multiplicidade que se produzem, constantemente, nos/com os cotidianos escolares, ainda que esse modo de pensar tenha possibilitado uma posição de partida importante. Conforme Certeau (1995, p. 145):

Um certo número de movimentos minoritários enfrenta a dificuldade de ter, em um primeiro momento, que se situar negativamente. Uma autonomia cultural, social ou étnica sempre se manifesta dizendo não: Não diz o negro, não sou um americano. Não diz o indiano, não sou um chileno ou um argentino. Não diz o bretão, não sou um francês. Essa é uma posição de partida absolutamente fundamental, mas rapidamente se torna 
enganosa quando se permanece nela: corre-se o risco de se agarrar quer a uma ideologia política, quer a uma formulação exclusivamente cultural.

Entretanto, para Certeau (1995), permanecer nessa posição é entrar no jogo que construiu o cultural como espetáculo e que instaura os elementos culturais como objetos de uma comercialização. Ademais, nessa dicotomia, a referência é sempre o que é hegemônico em determinado espaçotempo, produzindo no outro um sentimento de ser "diferente" ligado à designação dessa diferença pelo grupo dominante nessa circunstância, o que diminui a sua autonomia. $\mathrm{O}$ autor destaca ainda que os movimentos das minorias levantam uma questão geral relativa a toda a sociedade e indica que não há autonomia sem luta.

Assim compreendendo, defendemos que é possível examinar as práticas, entre elas, as acadêmicas e educativas, as que os produzem como tal. Mais do que dar visibilidade ao "diferente", como objeto do conhecimento, essência, categoria fixa ou fixada, resultado do grupamento de pessoas a partir de apenas um dos vários aspectos que as constituem, e que é ao mesmo tempo o negativo da identidade.

Da mesma maneira, a irredutibilidade de cada pessoa a um único aspecto de sua subjetividade, ao mesmo tempo única-múltipla, seja aquele informado pela significação atribuída à cor da pele, à genitália, à orientação sexual, à região geopolítica em que habita, à religião, à condição socioeconômica etc., nos leva a considerar que qualquer classificação é uma arbitrariedade, resultado de uma operação de significação metonímica (o todo por uma parte, física ou comportamental), e, assim, uma tentativa de reduzir a complexidade que constitui cada pessoa. Ao invés de potencializar essa operação, seria melhor, portanto, problematizá-la. Um caminho para essa problematização foi apontado pelo próprio Certeau (1994), quando propôs que con- 
siderássemos os sujeitos da vida cotidiana como praticantes, $\mathrm{o}$ que implica capturá-los não em essência (o que são, que cremos que são ou queremos que sejam), mas em atos.

A ideia de multiplicidade, como característica inerente ao cotidiano, nos leva a pensar que o que se produz com as práticas são diferenças, sendo as identidades, nessa perspectiva, dissimulações em relação a modelos vazios. A diferenciação, como processo, é o que caracteriza não só o movimento browniano da criação cultural, mas também própria vida. A diferença processual em relação não apenas aos outros, como a si mesmo, é, portanto, o que deve nos interessar. A afirmação da diferença, como processo vital e expansivo, desvinculada da identidade, da formatização da vida, das moldagens e das modulações é o que nos importa valorizar. Mas como afirmar que só existe diferença sem cair na indiferença em relação a todos aqueles marginalizados, subalternizados e/ou excluídos politicamente, socialmente e culturalmente em nossas sociedades?

Talvez, problematizando as operações que os produziram como "diferentes", como anormais, como minorias, para assim justificar a desigualdade produzida por essas e também por outras práticas (científicas, econômicas, bélicas, midiáticas, pedagógicas etc.). Talvez ainda, fazendo aparecer a complexidade e a multiplicidade que existe nos cotidianos, as negociações, as máscaras, os usos e as astúcias que produzem mestiçagens e põem em xeque, todo o tempo, as classificações.

Além, disso, uma tarefa nos foi proposta por Certeau (1995): a criação de razões para viver que sejam potentes para todos e para cada um. No que diz respeito a nós, educadores e pesquisadores, essa tarefa impõe, como questão de fundo, colocar em "debate o lugar do intelectual na sociedade e a experiência ou a concepção de cultura que resulta disso" (1995, p. 227). 
Trata-se ainda de assinalar a particularidade do nosso lugar e as dependências que ele implica.

Certeau, ao analisar os acontecimentos de seu tempo, nos advertiu para a necessidade de estar atentos às heteronomias, aos outros que estão em nós e que nos constituem. "O futuro nos chega às vezes, à nossa revelia, com as formações talvez “anárquicas e confusas", de mundos novos e diferentes" (1995, p. 231). Assim, essa outra sociedade no seio da que vivemos abre no presente possibilidades vindouras. Em resumo, como já havíamos destacado, o "futuro entra no presente sob a forma de alteridades” (p. 232), fazendo com que a vida se produza, sempre, na relação com os Outros. 


\section{CAPÍtULO 5}

\section{A pesquisa nos/dos/com os cotidianos em educação}

A partir, então, das ideias de Certeau - articuladas à noção de tessitura de conhecimentossignificações em redes nos cotidianos, proposta por Lefebvre (1983) — há mais de trinta anos, foram iniciados processos que deram origem à corrente de pensamento em pesquisa educacional que nomeamos de "Pesquisas nos/ dos/com os cotidianos" ou, simplesmente, "Pesquisas com os cotidianos". Soares (2013, p. 733) contextualiza o início desse movimento e sua vinculação à obra de Michel de Certeau, quando afirma que:

As ideias de Certeau foram apropriadas e trabalhadas, inicialmente, no pensamento educacional brasileiro dentro dos grupos de pesquisa de Nilda Alves e Regina Leite Garcia. Desde então, vêm multiplicando-se os pesquisadores que se reconhecem, diversificam e expandem essa corrente fazendo-a fluir e fruir, com maior concentração na Universidade do Estado do Rio de Janeiro, na Universidade Federal Fluminense e na Universidade Federal do Espírito Santo, mas disseminando-a também em outras instituições por todo o país. O foco desses pesquisadores está no exame das práticas cotidianas, das operações de praticantes (Certeau, 1994) que são engendradas em meio às redes de conhecimentos e significações, ou seja, às redes educativas dentrofora das escolas, ao mesmo tempo em que as engendram, tecendo permanentemente o social, o político, o econômico, o cultural, o tecnológico, e também, é claro, os processos educativos e curriculares. 
Cotidiano - ou cotidianos como preferimos afirmar atualmente na tendência de pesquisa em educação que foi se configurando como nos/dos/com os cotidianos - é o termo que utilizamos para buscar dar conta da dimensão criadora da vida e, principalmente da vida em sociedade, e dos diferentes modos de existência humana produzidos nos e produtores dos múltiplos espaçostempos em que ela se inventa e se realiza, dia após dia.

Cotidianos, portanto, é a palavra que usamos para nos referirmos à vida de todo dia e aos seus criadores que são, ao mesmo tempo, suas criações, simultaneamente, singulares e coletivas: os sujeitos - que somos e que vamos nos tornando as nossas práticas e os sentidos que a elas vamos atribuindo, tecendo e articulando redes de conhecimentos, de significações e de relações que vão constituindo nossas subjetividades e orientando nossas ações. Cotidianos, então, lugar de produção de conhecimentos, incluindo-se, entre eles, os valores, e de produção da existência.

Cotidianos escolares, nessa perspectiva, remetem às dimensões desses contextos cotidianos que abarcam a vida nas escolas, suas dinâmicas criadoras de conhecimentos e modos de existência e o enredamento destes com conhecimentos e modos de conhecer criados em outros contextos (mídias, ciências, artes, igrejas, movimentos sociais, estruturas de governo, vizinhança etc). A grafia no plural busca dar conta da heterogeneidade, da multiplicidade e das singularidades que os constituem. Cotidianos escolares remetem, portanto, ao contexto social no qual se produz o entrelaçamento das redes de conhecimentossignificações e sentidos tecidas dentrofora das escolas, com a finalidade de aprendermosensinarmos, formarmos e nos formarmos.

Para se compreender os cotidianos escolares como espaçotempos de criação e de articulação de conhecimentos, de emancipação e de invenção da vida, e não apenas como um do- 
mínio do social no qual só existe passividade, submissão, repetição, reprodução e consumo do que é criado em outros contextos (como as políticas educativas oficiais, as disciplinas científicas e o mercado). É preciso compreender que teorias, conceitos e esquemas de percepção e análise produzidos em tantos estudos sobre a educação - especialmente os atualmente tidos como tradicionais, mas ainda dominantes - constituem limites em relação ao que precisa ser tecido com as práticas (Alves, 2001), com os praticantespensantes e com as redes tecidas e entramadas nas escolas.

Essa tendência em pesquisa nos/dos/com os cotidianos apostou, desde o início, na centralidade práticas educativas, nas redes de práticasteorias engendradas nos cotidianos escolares como contingências para a criação de conhecimentos e de modos de conhecer, singulares e potentes. Essa crença, no sentido de um investimento, uma modalidade de afirmação (Certeau, 1994) mobilizou/mobiliza discussões permanentes sobre questões teórico-metodológicas e teórico-epistemológicas necessárias às pesquisas nos/com os cotidianos, que vêm sendo conformadas, desde então, por diversos pesquisadores a ela vinculados. Essas discussões articulam diálogos com diversos autores e as aprendizagens com as próprias pesquisas.

Além de Certeau, entre os teóricos da vida em sociedade que dedicaram especial atenção aos cotidianos com os quais estabelecemos diálogos estão Agnes Heller e Henri Lefebvre. Contudo, apesar dos importantes estudos realizados e da contribuição para o campo, estes compreenderam o cotidiano como um domínio/esfera da vida social conduzido e/ou submetido a alguma coisa que se pretende como não cotidiana. Lefebvre (1991) pensou o cotidiano como uma invenção do capital e da modernidade, como um domínio estrategicamente criado pela 
burguesia, onde o que existe é passividade e consumo, e que para libertar seu potencial criador é preciso uma revolução cultural estrategicamente conduzida por aqueles capazes de pensá-la e programá-la de fora do cotidiano. Nesse sentido, a incapacidade de superar os modos de pensar, sentir e agir produzidos nessa esfera resulta em alienação.

Em outra perspectiva, Michel de Certeau opera um duplo mecanismo para indicar o cotidiano como lugar de criação, invenção e antidisciplina. Em sua empreitada teórica, ele vai desconstruindo esses lugares que se pretendem como não cotidianos, desocultando as operação de poder que buscam produzi-los como tal. Ao mesmo tempo, vai dando visibilidade às práticas do dia a dia dos homens e mulheres comuns, aos seus modos operacionais e aos que fabricam e criam com os usos dos produtos, normas, leis, conhecimentos e significações postos ou impostos. Essas práticas, ao modo das táticas, desorganizam esses lugares estratégicos de controle. Os denominados praticantes - porque a princípio não fabricam o que usam -, no entanto, marcam com esses usos os desvios em relação ao que é dado e/ou imposto.

As Pesquisas nos/dos/com os cotidianos, inspiradas por Michel de Certeau, mas dialogando com outras/diferentes tendências em pesquisa no campo da Educação, diferenciam-se de tantos outros estudos que se focavam apenas nas análises das políticas educacionais, da disciplinarização dos saberesfazeres e das verificações em escolas concretas, buscando identificar apenas reprodução e faltas, deficiências, negatividades (Alves e Oliveira, 2001). 


\section{Questões teórico-metodológico-epistemológicas e Pesquisas nos/dos/com os cotidianos}

Vários livros lançados no final da década de 1990 e no início dos anos 2000 sistematizavam e divulgavam para um grupo mais amplo os estudos e as pesquisas que vinham sendo realizados por autores e autoras que integravam diferentes grupos de pesquisa. Entre eles, destacamos inicialmente dois que consideramos emblemáticos em relação à configuração do campo: O sentido da escola (Alves e Garcia, 1998) e Pesquisa no/do cotidiano: sobre redes de saberes (Alves e Oliveira, 2001).

No primeiro livro destacado, O sentido da escola, o texto “Tecer conhecimento em rede", de Nilda Alves, apresenta a metáfora da rede como imagem de um pensamento que procura compreender como os conhecimentos são criados numa lógica de conexões, articulações e entrelaçamentos de diversos outros conhecimentos e modos de conhecer, considerando a centralidade das práticas nesses processos. A metáfora da rede se opõe à da árvore, ainda dominante à época e quiçá atualmente em algumas teorias e políticas educacionais, com sua lógica linear e hierarquizante que orienta uma concepção de escola e de organização do trabalho escolar, implicando seriação, etapismo, grupalização etc., com maior dedicação às disciplinas consideras mais importantes para base sólida, geralmente as teóricas.

No segundo livro, Pesquisa no/do cotidiano: sobre redes de saberes, destacamos três textos. No primeiro deles, "Contar o passado, analisar o presente e sonhar o futuro", Alves e Oliveira lançam o desafio de pensar diferente desses tantos e outros estudos centrados no poder (tomado como algo transcendente, extra cotidiano) e apontam para a necessidade de buscar o que há de positivo nas escolas, o que lá se faz com as contingências que se tem. 
Tempos depois, em outro texto, "Cultura e cotidiano escolar", publicado em 2003, na Revista Brasileira de Educação, Alves indica outros autores com os quais dialogava na tessitura das questões teórico-epistemológicas e teórico-metodológicas referentes às pesquisas com os cotidianos. Nesse texto, ela aponta para a necessidade de ir além dos estudos que compreendem os cotidianos escolares com "caixas-pretas" (iniciados nos Estados Unidos), metáfora que sugere a impossibilidade de compreender o que lá se passa.

Considerando essa concepção insuficiente, Alves aponta estudos que aos poucos vão ultrapassando-a e ajudando-a a tecer outras possibilidades para se compreender os cotidianos escolares. Entre eles aqueles estudos associados à teorização de Gramsci e da Escola de Frankfurt, buscando compreender as relações entre as escolas e a realidade social mais ampla; os estudos de Stake, indicando a necessidade de cruzar fontes e a impossibilidade de generalizações em relação aos cotidianos escolares. Também há as pesquisas de Stenhouse, que desenvolve a ideia de professor-pesquisador, que à medida que vão questionando suas práticas, são os que podem efetivar intervenções nos cotidianos das escolas, assim como os estudos de Ezpeleta e Rockwell. Nesse texto Alves destaca ainda a importância dos Estudos Culturais, das contribuições de Boaventura de Souza Santos, e do próprio Certeau na configuração das questões teórico-metodológicas necessárias à compreensão dos cotidianos escolares.

Voltando ao livro Pesquisa no/do cotidiano (2001), destacamos o texto "Decifrando o Pergaminho", de Nilda Alves, no qual a pesquisadora, considerando as ideias de redes de conhecimentos e tessitura de conhecimento em redes, indica quatro movimentos fundamentais para a preparação dos pesquisadores nos/dos/com os cotidianos escolares. 
No primeiro deles, para começar, ela sugere um mergulho com todos os sentidos no que desejamos estudar. Ela chama esse movimento de sentimento de mundo. O segundo movimento, $v i$ rar de ponta cabeça, propõe uma inversão epistemológica: compreender como limite ao que precisa ser tecido aquilo que nos habituamos a ver como apoio (teorias, categorias, conceitos e noções). Considerando a complexidade do cotidiano, e assim a diversidade, o diferente e o heterogêneo, Alves propõe um terceiro movimento: beber em todas as fontes. Trata-se da necessidade de incorporar fontes variadas, vistas em outras épocas como indispensáveis ou até mesmo como suspeitas. A seguir, como o quarto movimento, ela indica que, para comunicar "novos achados", precisamos de outra maneira de escrever. A esse movimento Alves nomeia: narrar a vida e literaturizar a ciência.

Mas adiante, em uma retomada, segundo ela mesma, crítica em relação às questões metodológicas-epistemológicas das Pesquisas nos/dos/com os cotidianos, Alves, em um artigo publicado com data de 2003 na revista Teias, busca compreender o que ela não havia visto antes, mas que já estava há muito colocado: o que de fato interessa nas pesquisas nos/dos/com os cotidianos são as pessoas, os praticantes, com as chama Certeau porque as vê em atos, o tempo todo. Alves chama esse quinto movimento de Ecce femina. Ele diz respeito à compreensão da importância dos praticantes do cotidiano nas pesquisas e que, como ela mesma explica, só vai aparecer no texto escrito na medida em que a criação atualiza o virtual a partir da crítica no entrecruzamento de todos os diálogos estabelecidos após a publicação de seus textos anteriores. A ideia é homenagear Nietzsche e Foucault, apropriando o termo Ecce homo à realidade das escolas brasileiras. 


\section{Diferenças, aproximações e valores compartilhados}

Desde o início, as Pesquisas nos/dos/com os cotidianos, apesar da heterogeneidade de temas e de maneiras de fazer, buscam, em comum - um comum criado a partir das/com as diferenças, solidariedades e frequentações de seus pesquisadores dar visibilidade aos saberes e maneiras de fazer ordinários tecidos cotidianamente nas escolas e nas múltiplas redes educativas, no entrelaçamento das diversas redes que constituem cada um e todos os seus praticantespensantes. Ao mesmo tempo, buscam interrogar e colocar em xeque os mecanismos ocultos nos processos e nas lógicas operatórias que os tornam invisíveis.

Outros livros foram/são fundamentais na configuração dessa tendência em pesquisa no Brasil, como os dois volumes sobre metodologia organizados por Regina Leite Garcia: Método: pesquisa com o cotidiano e Método, métodos, contramétodos, ambos de 2003. Entre os textos dessa leva, destacamos, como importantes para a organização do campo, Dilemas para uma pesquisadora com o cotidiano, de Esteban, Itinerância de uma pesquisa, por Azevedo e Eu caçador de mim, de Ferraço, entre tantos desses e de outros autores.

Fazer Pesquisas nos/dos/com os cotidianos, para melhor compreendê-los e intervir (Esteban e Ferraço) nos processos educativos e nos currículos realizados (Ferraço) e/ ou praticados (Oliveira), alargando as redes tecidas e ampliando as possibilidades para o conhecimento (Ferraço), requer, contudo, uma atitude que vem sendo conformada coletivamente a partir de uma grande preparação (Garcia), exigindo a revisão e configuração permanente dos modos de abordagem e expressão dos conhecimentossignificações criados. 
Desde então - e no entrecruzamento dessas reavaliações, diálogos e incorporação de contribuição de diversos autores/textos que vão configurando o campo - , algumas outras questões vão se tornando fundamentais para aqueles que optaram por esse modo/tendência em pesquisa, entre idas e vindas, abandonos e resgates. Destacamos aqui algumas delas:

1) Cotidianos escolares e redes educativas são espaçostempos em que ensinamosaprendemos, formamos e somos formados em meio a redes de práticasteorias nas quais tecemos e entrelaçamos redes de conhecimentossignificações produzidos em vários contextos cotidianos em que todos os seus praticantespensantes vivem. Para compreender a potência criadora, emancipatória e política das praticasteorias educaticas cotidianas, é necessário compreender o que os praticantes fazem com o que lhes é posto ou imposto (projetos pedagógicos, políticas educativas, material didático, conteúdos curriculares etc.). Nesse sentido, é preciso disponibilizar todas as nossas antenas e sentidos para perceber o que os praticantes fabricam com os usos (Certeau, 1994), negociações, traduções e mímicas (Bhabha, 1998), marcando um desvio em relação ao que é dado.

2) Essa postura em pesquisa não implica ignorar as relações de poder, as pressões e opressões do dia a dia, as tecnologias de controle e os mecanismos de exclusão (das pessoas e dos saberesfazes). Ao contrário, as noções de tática e de estratégia são informadas e informam essas contingências. Trata-se, então, ao analisar as práticas, de investigar as relações e tensões sociais, desocultando mecanismos de controle e subordinação.

3) As noções de tessitura de conhecimentos em redes de significações e em redes de subjetividades apontam para a complexidade, a multiplicidade e a singularidade que constituem os 
processos cotidianos de produzir significados e de constituição dos sujeitos, de produção de sentidos sobre si e sobre o mundo, como abertura para a alteridade e para a produção de novos/outros possíveis. Nesse sentido, assumir essas noções como lógica dos cotidianos implica a inutilidade operatória das dicotomias para se compreender como são criados os conhecimentos e as estéticas de existência. Pares binários como identidade/diferença; sujeito/objeto; aprender/ensinar; conhecimento científico/ conhecimento escolar; realidade/ficção; dentro da escola/fora da escola; políticas educativas/práticas escolares; teorias/práticas; documentos curriculares/currículos praticados, entre outros, não nos servem mais.

Assumir que os conhecimentos são tecidos em redes, no entrelaçamento de tantas outras redes, e que cada um de nós é uma rede de subjetividades implica uma compreensão diferenciada que supere grupamentos, classificações, oposições e hierarquização dos saberesfazeres, dos modos de conhecer, dos modos de existência, e também das pessoas em suas singularidades-múltiplas. Requer, ainda, uma disponibilidade para compreender os hibridismos (Bhabha, 1989), não como mixagem, mas como superposições; e desconstruir os binarismos historicamente produzidos, buscando permanentemente desocultar as práticasteorias que o produzem. A noção de redes de subjetividades aponta para a complexidade que constitui cada pessoa e revela a inutilidade de atendê-la a partir de um único aspecto, biológico, comportamental ou cultural, que a defina. Se concordamos que os cotidianos escolares são espaçostempos de multiplicidade, precisamos assumir que só há diferenças (como resultados dos usos, negociações, traduções e mímicas), diferenciações como processo vitais, imprevisíveis e incontroláveis. 
4) Ao problematizar os cotidianos escolares e as múltiplas redes educativas, precisamos, ainda, assumir que os currículos escolares são, o tempo todo, criados em redes, cotidianamente, dentrofora das escolas, com as políticas curriculares produzidas e negociadas em outros contextos. Ainda que as diretrizes curriculares e as teorias que procuram nos ensinar como se deve proceder com os currículos e os conhecimentos legitimados pelas disciplinas científicas, que são considerados conteúdos, tenham sido produzidas em outros espaçostempos, também cotidianos. Desse modo, como explica Ferraço (2005), tem sido cada vez mais difícil, nas redes cotidianas tecidas pelos praticantespensantes, identificar com nomes (tais como planejamento, gestão, ensino, avaliação, aprendizagem etc.) o que acontece nas escolas e quem são seus autores. Tudo acontece ao mesmo tempo com todos, indica o pesquisador.

5) É preciso também ressaltar, então, a importância que atribuímos aos praticantespensantes das escolas, compreendendo cada um como uma rede de subjetividades. Praticantes, como os denominou Certeau, e praticantespensantes como denomina Oliveira (2012), porque são apreendidos e considerados em atos. As relações e os conhecimentossignificações tecidos em redes nos cotidianos das escolas portam, portanto, as marcas de resistência, insubmissão, criação, articulação e invenção daqueles que de uma forma ou de outra, o protagonizam: professores, alunos, pedagogos, diretores, coordenadores, serventes, vigias, pais e familiares, entre outros. Esses são os sujeitos/autores não só dessas práticasteorias, mas também das nossas pesquisas com os cotidianos e, como nós pesquisadores, se transformam nos espaçostempos de nossas intervenções ao mesmo tempo em que transformam a organização desses espaçostempos. 
6) As práticasteorias educativas cotidianas são também práticas políticas. Em suas operações de usuários do que é posto ou imposto, nas artes de fazersaber, esses sujeitos se constituem e criam conhecimentos, relações e modos de existência contra-hegemônicos que desorganizam as tentativas de controle, governabilidade e formatização da vida conforme os interesses hegemônicos. Essa lógica operacional é conformada por táticas (Certeau), ou seja, ações informadas pela oportunidade e ocasião, e empreendidas por aqueles em que determinadas relações e contingências estão sob o poder/autoridade/ordem conformadas pelas estratégias que organizam o lugar, mas que não se submetem a elas, burlando-as e transgredindo-as para tornar esse lugar habitável e instituir outras possibilidades de viver, criar, existir e aprenderensinar. Nos usos, traduções, negociações e mímicas que fazem das políticas educativas, da organização do trabalho escolar, das grades curriculares, dos conteúdos das disciplinas e dos diversos artefatos escolares, os praticantespensantes criam tática, estrategicamente e em redes, novos conhecimentossignificações e novas possibilidades de existência.

7) Considerando a multiplicidade e a complexidade que caracterizam os cotidianos, precisamos de todas as nossas antenas para captá-los e compreendê-los. Da mesma forma, necessitamos de diversas linguagens e modos de expressão para comunicar nossos achados. Precisamos de procedimentos em pesquisa que nos possibilitem captar o que os cotidianos escolares nos dizem (fotos, gravações em vídeo, anotações em diários, cadernos, cartazes, bilhetes, sons, cheiros, sabores e principalmente as narrativas - verbais e imagéticas - dos praticantespensantes).

8) Da mesma forma, as análises sobre o que capturamos e produzimos com nossas pesquisas e a expressão dos conhe- 
cimentossignificações criados com os cotidianos devem acontecer, na medida do possível, de modo a se tornar compreensível e atraente para todos, contemplando a pluralidade. É por isso que nossos relatos de pesquisa assumem a forma de narrativas do presente e do vivido. Sempre polifônicas, múltiplas, complexas, híbridas, constituindo entre-lugares nos quais se articulam diversas narrativas, verbais e imagéticas, de praticantes, todas elas atravessadas por tantas outras que não poderão, nunca, ser dissociadas e identificadas. Esse procedimento ainda requer, a todo o tempo, cuidados éticos, estéticos e políticos em relação aos modos como se dará a ver e ao que se dará a ver, tendo em consideração os praticantespensantes, seus saberesfazeres, seus desejos, seus interesses, suas realidades.

9) As redes de conhecimentossignificações tecidas nos/com os cotidianos são efêmeras e se constituem diante das demandas da vida para logo se desvanecer. É preciso assumir a impossibilidade de apreender tudo o que acontece. Devemos supor, então, que podemos ter acesso apenas a alguns fios dessas redes e enquanto elas estão sendo tecidas.

Por fim, pensamos ser necessário destacar três questões - entre outras - que se relacionam e que nos ajudam a problematizar e complexificar o que temos chamado de Pesquisas nos/ dos/com os cotidianos. A primeira delas nos é dada por Soares (2010, p. 67), quando afirma que essas pesquisas não buscam se constituir como um bloco homogêneo, mas incluem diversas possibilidades de combinações, apropriações, traduções e negociações com e entre diversos autores, atores, conceitos e práticas.

Em seu conjunto, elas vêm constituindo um movimento antidisciplinador dos saberesfazeres, contra a hierarquização dos fazeressaberes e em oposição à marginalização/ exclusão que uma hierarquização promove; um movi- 
mento dinâmico, aberto, cambiante e em constante ação-reflexão-ação, que assume os riscos, as incertezas e os acasos no seu tatear, em conexão com a vida, no tempoespaço em que ela pulsa e se transforma.

Também é preciso afirmar que nós, pesquisadores nos/ dos/com os cotidianos, temos interesses em pesquisa múltiplos e cambiantes, abarcando diferentes temáticas que atravessam a Educação. São temáticas como currículo, avaliação, formação de professores, práticas docentesdiscentes, usos das mídias e tecnologias da comunicação e informação, aprendizagens com as artes e com os espaçostempos das cidades, a diáspora dos afrodescendentes, a intolerância religiosa, o racismo e as disputas em torno das questões de gênero e sexualidade, entre outros. Em comum, a atitude de insubmissão ao que é imposto, ao que inferioriza e marginaliza, ao que deslegitima as escolas e seus praticantespensantes; e a criação de outras possibilidades diante do que nos oprime, restringe e/ou constrange.

A segunda questão a ser reafirmada é apontada por Ferraço (2003), ao defender a importância de, durante a pesquisa, pensarfazer com os praticantespensantes, e não para ou sobre eles, assumindo, como defende Oliveira (2012), essa condição de todos nós nas redes cotidianas. Para o autor, essa atitude de pensarfazer "com" o Outro na pesquisa implicaria superar as abordagens que privilegiam os protagonismos, as individualidades e/ou as personificações, indo ao encontro dos processos, das relações, das redes tecidas. Como defende Ferraço (2016, p. 45):

Esta busca de estabelecer uma proximidade com o outro na pesquisa não resulta em uma abordagem pessoal, individualista, mas vai ao encontro do que se passa entre as pessoas, isto é, privilegia as relações que se estabelecem nos/com os encontros, dedica especial atenção ao que é tecido entre elas. Assim, em nossas pesquisas com 
os cotidianos das escolas, nossa atenção está voltada para as práticas realizadas nas redes tecidas e compartilhadas pelos sujeitos, buscando, sempre que possível, superar uma abordagem centrada no indivíduo.

Alves (2010) nos informa sobre a terceira questão, quando infere que problematizar os cotidianos com nossas pesquisas implica não só questionar as dicotomias herdadas do discurso hegemônico da ciência moderna, mas, sobretudo, indicar que estão equivocados aqueles que "suspeitam" que não há política nos cotidianos. Nas palavras de Alves (2010, p. 49),

Para começar precisamos dizer que não existe, nas pesquisas com os cotidianos, entre os inúmeros grupos que as desenvolvem, a compreensão de que existem práticas e políticas [...] uma vez que entendemos que as políticas são práticas, ou seja, são ações de determinados grupos políticos sobre determinadas questões com a finalidade explicitada de mudar algo existente em um campo de expressão humana. Ou seja, vemos as políticas, necessariamente, como práticas coletivas dentro de um campo qualquer no qual há, sempre, lutas de posições diferentes e, mesmo, contrárias. Desta maneira, não vemos como 'políticas' somente as ações que são mais visíveis. Os grupos não hegemônicos, em suas ações, produzem políticas que, muitas vezes, não são visíveis aos que analisam 'as políticas' porque estes foram formados para enxergar, exclusivamente, o que é hegemônico com o que aprenderam com o modo de pensar hegemônico. 


\section{Referências}

ALVES, Nilda. "Decifrando o pergaminho - o cotidiano das escolas nas lógicas das redes cotidianas". In OLIVEIRA, I. B. de e ALVES, N. (orgs.). Pesquisa no/do cotidiano das escolas - sobre redes de saberes. Rio de Janeiro: DP \& A, 2001.

. "Cultura e cotidiano escolar". Rev. Bras. Educ, n. 23, pp. 62-74, 2003. Disponível em: http://www.scielo.br/scielo.php?pi$\mathrm{d}=\mathrm{S} 1413-24782003000200005 \& \mathrm{script}=\mathrm{sci} \_$abstract $\& \operatorname{tlng}=\mathrm{pt}$. Acesso em: 3 nov. 2016.

- "Sobre movimentos das pesquisas nos/dos/com os cotidianos”. Revista Teias, v. 4, pp. 1-8, Rio de Janeiro, PROPEd/UERJ, 2007.

- 'Redes educativas 'dentrofora' das escolas, exemplificadas pela formação de professores”. In DALBEN, Ângela et al. (eds.). Convergências e tensões no campo da formação e do trabalho docente. Belo Horizonte: Autêntica, 2010, pp. 49-66.

e OLIVEIRA, I. B. de. "Contar o passado, analisar o presente e sonhar o futuro". In OLIVEIRA, I. B. de e ALVES, N. (orgs.). Pesquisa no/do cotidiano das escolas: sobre redes de saberes. Rio de Janeiro: DP\&A, 2001.

e GARCIA, R. L. (orgs.). O sentido da escola. Rio de Janeiro: DP\&A, 1998. 
AZEVEDO, Joanir. "Itinerâncias da pesquisa". In GARCIA, R. L. (org.). Método: pesquisa com o cotidiano. Rio de Janeiro: DP\&A, 2003.

BHABHA, Homi K. O local da cultura. Belo Horizonte: Ed. UFMG, 1998.

CERTEAU, Michel de. A invenção do cotidiano: artes de fazer. Petrópolis: Vozes, 1994, v. 1.

. A cultura no plural. Campinas: Papiros, 1995.

. A escrita da história. Rio de Janeiro: Forense Universitária, 2006.

. História e psicanálise: entre ciência e ficção. Belo Horizonte: Autêntica, 2011.

CRAVETTO, Maria Letizia. “L'émancipation de la pensée. À propos de l'oeuvre de Michel de Certeau”. Diogène, n. 199, pp. 135-51, Presses Universitaires de France, 2002-3. Diponível em: http:// www.cairn.info/revue-diogene-2002-3-page-135.htm.

DELEUZE, Gilles. Conversações. Trad. Peter Pál Pelbart. Rio de Janeiro: Ed. 34, 1992.

DETIENNE, Marcel e VERNANT, Jean Pierre. Métis: as astúcias da inteligência. São Paulo: Odysseus Editora, 2008.

ESTEBAN, M. T. “Dilemas para uma pesquisadora com o cotidiano”. In GARCIA, R. L. (org.). Método: pesquisa com o cotidiano. Rio de Janeiro: DP\&A, 2003.

FERRAÇO, C. E. "Eu, caçador de mim”. In GARCIA, R. L. (org.). Método: pesquisa com o cotidiano. Rio de Janeiro: DP\&A, 2003. 
FERRAÇO, C. E. "Currículo, formação continuada de professores e cotidiano escolar: fragmentos de complexidade das redes vividas”. Cotidiano escolar, formação de professores(as) e currículo. São Paulo: Cortez, 2005. . Currículos em redes. Curitiba: CRV, 2016.

GARCIA, Regina Leite (org.). Método: pesquisa com o cotidiano. Rio de Janeiro: DP\&A, 2003.

. Método, métodos, contramétodos. São Paulo: Cortez, 2003.

GIARD, Luce. "História de uma pesquisa”. In CERTEAU, Michel de. A invenção do cotidiano: Artes de fazer. Petrópolis: Vozes, 1994, v. 1.

. “A invenção do possível”. In CERTEAU, Michel de. A cultura no plural. Campinas: Papiros, 1995.

. "Momentos e lugares". In CERTEAU, Michel de et al. A invenção do cotidiano: morar, cozinhar. Petrópolis, RJ: Vozes, 1996, v. 2.

. "Biografia de Michel de Certeau" (mimeo). Campinas, 2006.

. "Um caminho não traçado". In CERTEAU, Michel de. História e psicanálise: entre ciência e ficção. Belo Horizonte: Autêntica, 2011.

JOSGRILBERG, Fábio Botelho. Cotidiano e invenção: os espaços de Michel de Certeau. São Paulo: Escrituras, 2005.

LEFEBVRE, H. A vida cotidiana no mundo moderno. São Paulo: Ática, 1991. 
MAYOL, Pierre. “O bairro”. In CERTEAU, Michel de et al. A invenção do cotidiano: morar, cozinhar. Petrópolis, RJ: Vozes, 1996, v. 2.

OLIVEIRA, Inês Barbosa de. "Currículos e pesquisas com os cotidianos: o caráter emancipatório dos currículos 'pensadospraticados' pelos 'praticantespensantes' dos cotidianos das escolas”. In FERRAÇO, Carlos Eduardo e CARVALHO, Janete Magalhães Carvalho (orgs.). Currículos, pesquisas, conhecimentos e produção de subjetividades. Petrópolis: DP et Alli, 2012, pp. 47-70.

e ALVES, N. (orgs.). Pesquisa no/do cotidiano das escolas: sobre redes de saberes. Rio de Janeiro: DP\&A, 2001.

QUADROS, Eduardo Gusmão de. "A experiência viva: uma introdução a história religiosa de Michel de Certeau". Anais do Simpósio CEHILA Brasil. Goiás, 2002.

SCHMITT, Jean-Claude. "A moral dos gestos”. In SANT’ANNA, Denise Bernuzzi de. Políticas do corpo: elementos para uma história das práticas corporais. São Paulo: Estação Liberdade, 2005.

VIDAL, Diana. "Michel de Certeau e a difícil arte de fazer história das práticas". In FARIA FILHO, Luciano Mendes de. Pensadores sociais e história da educação. Belo Horizonte: Autêntica, 2005.

SOARES, Maria da Conceição Silva. "Pesquisas com os cotidianos: devir-filosofia e devir-arte na ciência”. Educação \& Realidade, v. 38, n. 3, pp. 731-45, Porto Alegre, jul.-set. 2013. 


\section{Sobre os autores}

Carlos Eduardo Ferraço - É professor associado da Universidade Federal do Espírito Santo (UFES), atuando no Centro de Educação e no Programa de Pós-graduação Educação (PPGE). É coordenador do Grupo de Pesquisa CNPq Currículos, cotidianos, culturas e redes de conhecimentos. É bolsista de produtividade de pesquisa do CNPq e vice-presidente/Região Sudeste da Associação Nacional de Pós-Graduação e Pesquisa em Educação/ANPEd. CV: http://lattes.cnpq. br/4231564319302829.

Maria da Conceição Silva Soares - Professora adjunta da Universidade do Estado do Rio de Janeiro (UERJ), atuando na Faculdade de Educação e no Programa de Pós-graduação em Educação (PROPED). Coordenadora do Grupo de Pesquisa CNPq Currículos, Narrativas Audiovisuais e Diferença. Procientista/UERJ. Cientista Nosso Estado/FAPERJ. CV: http://lattes. cnpq.br/0966985292376989.

Nilda Alves - Professora visitante do Programa de Pós-graduação em Educação (PROPED) da Universidade do Estado do Rio de Janeiro. Professora titular aposentada da UERJ e professora titular aposentada da UFES. Coordenadora do Grupo de Pesquisa CNPq Currículos, redes educativas e imagens. É bolsista de produtividade de pesquisa $1 \mathrm{~A}$ do CNPq. CV: http:// lattes.cnpq.br/4233172979202700. 